\title{
Ruthenium(II)-mercapto Complexes with Anticancer Activity Interact with Topoisomerase IB
}

\author{
Monize M. da Silva, ${ }^{* a}$ Mariana S. de Camargo, ${ }^{a}$ Silvia Castelli, ${ }^{b}$ Rone A. de Grandis, ${ }^{c}$ \\ Eduardo E. Castellano, ${ }^{d}$ Victor M. Deflon, ${ }^{e}$ Marcia R. Cominetti, ${ }^{f}$ Alessandro Desideri ${ }^{b}$ \\ and Alzir A. Batista ${ }^{\odot *, a}$
}

${ }^{a}$ Departamento de Química, Universidade Federal de São Carlos, CP 676, 13565-905 São Carlos-SP, Brazil

${ }^{b}$ Dipartimento di Biologia, Università Tor Vergata di Roma, 00133 Rome, Italy

c Departamento de Ciências Biológicas, Faculdade de Ciências Farmacêuticas, Universidade Estadual Paulista (Unesp), 14801-902 Araraquara-SP, Brazil

${ }^{d}$ Instituto de Física de São Carlos, Universidade de São Paulo, CP 369, 13560-970 São Carlos-SP, Brazil

${ }^{e}$ Instituto de Química de São Carlos, Universidade de São Paulo, CP 780, 13560-970 São Carlos-SP, Brazil

${ }^{f}$ Departamento de Gerontologia, Universidade Federal de São Carlos, CP 676, 13565-905 São Carlos-SP, Brazil

\begin{abstract}
Herein we present four new ruthenium(II) complexes: [Ru(mtz) $\left.{ }_{2}(\mathrm{dppb})\right](\mathbf{1})$, $\left[\mathrm{Ru}(\mathrm{mmi})_{2}(\mathrm{dppb})\right](\mathbf{2}),\left[\mathrm{Ru}(\mathrm{dmp})_{2}(\mathrm{dppb})\right](\mathbf{3})$, and $\left[\mathrm{Ru}(\mathrm{mpca})_{2}(\mathrm{dppb})\right](\mathbf{4})$, where $\mathrm{mtz}=2$-mercaptothiazoline; $\mathrm{mmi}=2$-mercapto-1-methyl-imidazole; $\mathrm{dmp}=4,6$-diamino2 -mercaptopyrimidine; mpca $=6$-mercaptopyridine-3-carboxylic acid; $\mathrm{dppb}=1,4$-bis(diphenylphosphino)butane. In vitro cell culture experiments revealed cytotoxic activity for complexes 2, 3 and $\mathbf{4}$ against MCF-7 (breast, non-invasive), MDA-MB-231 (breast, invasive), A549 (lung), DU-145 (prostate) and HepG2 (liver) tumor cells, in some cases lower than the half maximal inhibitory concentration $\left(\mathrm{IC}_{50}\right)$ for the reference drug (cisplatin). The deoxyribonucleic acid (DNA) interactions studied by viscosity measurements, gel electrophoresis and square-wave voltammetry indicated that the DNA binding affinity primarily occurs through non-covalent interactions. Only complex $\mathbf{2}$ was able to fully inhibit the DNA supercoiled relaxation mediated by human topoisomerase IB (Top IB). The analysis indicates that complex 2 inhibits the cleavage and the reconnection steps of the catalytic cycle, being both a poison and a catalytic inhibitor.
\end{abstract}

Keywords: ruthenium(II) complexes, mercapto ligands, cytotoxicity, topoisomerase IB

\section{Introduction}

Mercapto molecules have been used as ligands to prepare compounds with different biological activities, mainly because they already have some antitumor and antiviral activities and may have synergistic effects when coordinated to the metal. ${ }^{1-4}$ These characteristics make the interaction of mercapto ligands with heavy metals of particular interest for the synthesis of complexes that could be potential metalodrugs. ${ }^{3}$

*e-mail: monize_martins@yahoo.com.br; daab@ufscar.br
Metal complexes, which efficiently bind and cleave deoxyribonucleic acid (DNA) under physiological conditions stopping the reconnection of the biomolecule, can be considered as potential candidates for use as therapeutic agents against cancer, and thus should be considered as an issue deserving further scrutiny. ${ }^{5-8}$

Ruthenium compounds with bidentate ligands are not very toxic and some of them have shown to be quite selective for cancer cells. Thus, this class of complexes has advantages compared to platinum drugs, showing greater selectivity for cancer cells, leading to reduced side effects. These complexes have also demonstrated cytotoxic activity 
against cells resistant to cisplatin and some ruthenium complexes have shown antimethastatic properties. ${ }^{9-12}$ In cancer therapy, the focus is on promising rutheniumbased complexes such as TLD-1433 ([Ru' $(4,4$ '-dimethyl2,2'-bipyridine)2(2-(2',2":5",2"'-terthiophene)-imidazol $[4,5-f][1,10]$ phenathroline $\left.)]^{2+}\right)$ and NKP1339 ([Na] $\left[\right.$ trans $\left.\left.-\mathrm{RuCl}_{4}(\mathrm{Ind})_{2}\right]\right){ }^{13,14}$ The compounds known as NAMI-A $\left([\mathrm{ImH}]\left[\right.\right.$ trans $\left.\left.-\mathrm{RuCl}_{4}(\mathrm{DMSO}-\mathrm{S})(\mathrm{Im})\right]\right), \mathrm{Im}=$ imidazole $)$ and $\mathrm{KP} 1019$ ([IndH][trans-RuCl$\left.(\mathrm{Ind})_{2}\right]$, Ind = indazole) have achieved success in clinical studies, but they showed only limited efficacy, which prevented further clinical development of these compounds.

There are in the literature many new potential anticancer drugs developed, which interfere with the DNA metabolism and/or hinder the function of DNA processing enzymes, such as topoisomerases. ${ }^{15}$ Topoisomerase enzymes are able to reduce tension during the DNA replication process, transcription, recombination and chromosome segregation in the cell cycle, and are activated during the cancer cell growth. ${ }^{16}$ Thus, topoisomerase enzymes, which have the capability to cleave one strand (topoisomerase I) or two strands (topoisomerase II) of DNA, allowing it to unwind and then reconnecting the polynucleotide chain, are possible targets for anticancer agents. ${ }^{17}$ Topoisomerase IB is the target of a large number of drugs, and depending on their action, they can be divided into catalytic inhibitors and poison inhibitors. ${ }^{18}$ Poisons inhibitors include drugs used clinically, such as those derived from the natural product camptothecin, which reversibly binds the DNA, forming one top-DNA covalent complex that inhibits the reconnection of the cleaved DNA chain, inducing cell death. Catalytic inhibitors prevent binding to DNA topoisomerase I or inhibit the enzyme cleavage reaction, and thus inhibit the relaxation of DNA. ${ }^{19,20}$

In view of our effort to develop new ruthenium complexes as potential antitumor agents, in this report we present the synthesis and characterization of four new ruthenium complexes, namely, $\left[\mathrm{Ru}(\mathrm{mtz})_{2}(\mathrm{dppb})\right](\mathbf{1})$, $\left[\mathrm{Ru}(\mathrm{mmi})_{2}(\mathrm{dppb})\right](\mathbf{2}),\left[\mathrm{Ru}(\mathrm{dmp})_{2}(\mathrm{dppb})\right](\mathbf{3})$ and $\left[\mathrm{Ru}(\mathrm{mpca})_{2}(\mathrm{dppb})\right](4)$, where $\mathrm{mtz}=2$-mercaptothiazoline; $\mathrm{mmi}=2$-mercapto-1-methyl-imidazole; $\mathrm{dmp}=4,6$-diamino2 -mercaptopyrimidine; $\mathrm{mpca}=6$-mercaptopyridine3-carboxylic acid; dppb = 1,4-bis(diphenylphosphino) butane and bipy $=2,2$ '-bipyridine. The cytotoxicity of these compounds was evaluated against different tumor cells: the breast cancer cells, MCF-7 (ATCC No. HTB-22) and MDA-MB-231 (ATCC No. HTB-26), the human lung tumor line, A549 (ATCC No. CCL-185), the human prostate cancer cell DU-145(ATCC No. HTB-81), the human hepatocellular carcinoma HepG2 (purchased from the Rio de Janeiro Cell Bank, Brazil) and Homo sapiens lung normal cells, MRC-5 (ATCC No. CCL-171). The capacity of the compounds to interact with DNA were studied by different techniques, and the inhibitory activity of the complexes against topoisomerase IB (Top IB), was also carried out.

The ruthenium complexes studied here were rationally designed considering the property of the diphosphine to stabilize the metal center and the possibility of the mercapto ligands, when coordinated, to form neutral complexes, which could only weakly interact with the DNA or with other biomolecules, through the rigid ring of these molecules, probably by $\pi-\pi$ interactions.

\section{Experimental}

\section{General}

Reactions and chemicals were handled under argon atmosphere. The solvents were purified by standard methods. All chemicals used were of reagent grade or comparable purity. The $\mathrm{RuCl}_{3} \cdot 3 \mathrm{H}_{2} \mathrm{O}$, ligands 2-mercaptothiazoline; 2-mercapto-1-methyl-imidazole; 4,6-diamino-2-mercaptopyrimidine; 6-mercaptopyridine3-carboxylic acid and 1,4-bis(diphenylphosphino)butane were supplied by Aldrich (Saint Louis, Missouri, USA) and used as received. The precursor $\left[\mathrm{RuCl}_{2}(\mathrm{dppb})\left(\mathrm{PPh}_{3}\right)\right]$, was prepared according to the published procedures. ${ }^{21,22}$

The infrared spectra of the complexes were obtained using CsI pellets in a FTIR Bomem-Michelson 102 spectrometer in the $4000-250 \mathrm{~cm}^{-1}$ region. UV-Vis spectra were recorded in a HP8452A (diode array) spectrophotometer. Cyclic voltammetry experiments were performed in an electrochemical Princeton Applied Research Potentiostate/Galvanostate model 273A, and were carried out at room temperature. Conditions: $\mathrm{CH}_{2} \mathrm{Cl}_{2}$ containing $0.10 \mathrm{~mol} \mathrm{~L}^{-1}$ of $\mathrm{Bu}_{4} \mathrm{NClO}_{4}$ (TBAP) as a support electrolyte, using an electrochemical cell with a three-electrode system: platinum as a working electrode, $\mathrm{Ag} / \mathrm{AgCl} / \mathrm{KCl}$ as a reference electrode and platinum plate as an auxiliary electrode, in which condition, ferrocene is oxidized at $0.43 \mathrm{~V} v s$ normal hydrogen electrode (NHE). The microanalyses were performed in the Microanalytical Laboratory at the Universidade Federal de São Carlos, São Carlos-SP, Brazil, with an EA 1108 CHNS microanalyzer (Fisons Instruments). Conductivity values were obtained at room temperature, using $10^{-3} \mathrm{M}$ solutions of the complexes in $\mathrm{CH}_{2} \mathrm{Cl}_{2}$, by a Meter Lab CDM2300 instrument. ${ }^{1} \mathrm{H},{ }^{31} \mathrm{P}\left\{{ }^{1} \mathrm{H}\right\}$ and ${ }^{13} \mathrm{C}\left\{{ }^{1} \mathrm{H}\right\}$ nuclear magnetic resonance (NMR) were recorded on a Bruker DRX $400 \mathrm{MHz}$, internally referenced to tetramethylsilane (TMS), chemical shift $(\delta)$, multiplicity $(\mathrm{m})$, spin-spin coupling constant $(J)$, integral $(\mathrm{I}) . \mathrm{CDCl}_{3}$ was 
used as solvent, unless mentioned. The ${ }^{31} \mathrm{P}\left\{{ }^{1} \mathrm{H}\right\}$ shifts are reported in relation to $\mathrm{H}_{3} \mathrm{PO}_{4}, 85 \%$, in $\mathrm{CD}_{2} \mathrm{Cl}_{2}$.

Single crystals of 1-4 were obtained at room temperature from dichloromethane/methanol/ether (1:1:3) solutions and were mounted on glass fibers. An Enraf-Nonius Kappa-CCD diffractometer (for $\mathbf{1}$ and $\mathbf{2}$ ) and a Bruker Kappa APEX II Duo diffractometer (for 3 and 4), both equipped with graphite monochromated Mo K $\alpha$ radiation $(\lambda=0.71073 \AA)$, were used for intensity data collection at room temperature. The structures were solved with SHELXS and refined using SHELXL software ${ }^{23}$ with anisotropic thermal displacements for all non-hydrogen atoms. The hydrogen atoms were placed at theoretically ideal positions and refined isotropically as riding atoms. Gaussian (for $\mathbf{1}$ and 2) and Multi-scan (for $\mathbf{3}$ and 4) absorption correction methods were applied. Residual electron density, localized in voids, was treated applying the SQUEEZE routine of PLATON ${ }^{24}$ for 3 (2085 $\AA^{3}$ total potential solvent accessible volume, totaling $340 \mathrm{e}-$, consistent with eight molecules of dichloromethane and/or ether per unit cell, since each of both solvent molecules has $42 \mathrm{e}$-, totalizing $336 \mathrm{e}-$ ) and 4 ( $481 \AA^{3}$ of solvent accessible volume, totaling $68 \mathrm{e}-$, corresponding to four molecules of methanol per unit cell). More information about the crystal structure and refinement data for 1-4 is depicted in Table S1.

\section{Synthesis}

Complexes 1-4 were prepared in a Schlenk tube containing $30 \mathrm{~mL}$ of $\mathrm{CH}_{2} \mathrm{Cl}_{2}$ (deaerated previously). Then, $0.24 \mathrm{mmol}$ of the ligand and $32 \mu \mathrm{L}$ of triethylamine was added to the Schlenk. Afterwards, $0.11 \mathrm{mmol}$ of the precursor $\left[\mathrm{RuCl}_{2}(\mathrm{dppb})\left(\mathrm{PPh}_{3}\right)\right]$ was added and the solution was stirred for $12 \mathrm{~h}$ under $\mathrm{Ar}$ atmosphere. The final yellow solutions were concentrated to about $2 \mathrm{~mL}$ and diethyl ether was added, to obtain yellow precipitates. The solids were filtered off, well rinsed with water $(5 \times 5 \mathrm{~mL})$ and diethyl ether $(3 \times 5 \mathrm{~mL})$ and dried in vacuo.

\section{Complex $1\left(\left[\mathrm{Ru}(\mathrm{mtz})_{2}(\mathrm{dppb})\right]\right)$}

Yield of $75 \mathrm{mg}(0.10 \mathrm{mmol}, 89 \%)$; anal. calcd. for $\mathrm{C}_{34} \mathrm{H}_{36} \mathrm{~N}_{2} \mathrm{P}_{2} \mathrm{RuS}_{4}$ : exptl. (calcd.) C 53.13 (53.45), H 4.45 (4.75), N 3.59 (3.67), S 16.41 (16.79); ${ }^{31} \mathrm{P}\left\{{ }^{1} \mathrm{H}\right\}$ NMR (161.98 $\left.\mathrm{MHz}, \mathrm{CH}_{2} \mathrm{Cl}_{2} / \mathrm{D}_{2} \mathrm{O}\right) \quad \delta 52.88(\mathrm{~s}) ;$ molar conductance / $\left(\Omega^{-1} \mathrm{~cm}^{2} \mathrm{~mol}^{-1}, \mathrm{CH}_{2} \mathrm{Cl}_{2}, 1.0 \times 10^{-3} \mathrm{M}\right) 0.96 ; \mathrm{IR}(\mathrm{CsI}) \mathrm{v} / \mathrm{cm}^{-1}$ $(v \mathrm{C}-\mathrm{H}) 3137,3051,\left(v \mathrm{CH}_{2}\right) 2912,2853,(v \mathrm{C}=\mathrm{C} / \mathrm{C}=\mathrm{N}) 1588$, $1531,(v \mathrm{~N}=\mathrm{C}+\delta \mathrm{CH}) 1434,(v-\mathrm{C}=\mathrm{C}($ ring $)+v \mathrm{C}=\mathrm{C}(\mathrm{dppb}))$ $1485,1296,(\nu \mathrm{C}=\mathrm{S}) 1254,(\nu \mathrm{C}-\mathrm{S}) 1185$, ( $\left.v \mathrm{C}-\mathrm{P}_{\text {ring }}\right) 1088$, ( $v \mathrm{C}-\mathrm{P})$ 740, ( $v \mathrm{C}-\mathrm{P})$ 512, ( $(\mathrm{Ru}-\mathrm{P})$ 518, 491, ( $v \mathrm{Ru}-\mathrm{S})$ 440, $(v \mathrm{Ru}-\mathrm{N})$ 423; UV-Vis $\left(\mathrm{CH}_{2} \mathrm{Cl}_{2}, 1.27 \times 10^{-5} \mathrm{M}\right) \lambda / \mathrm{nm}$ $\left(\varepsilon / \mathrm{M}^{-1} \mathrm{~cm}^{-1}\right) 234$ (78405), 304 (10957).

\section{Complex $2\left(\left[\mathrm{Ru}(\mathrm{mmi})_{2}(\mathrm{dppb})\right]\right)$}

Yield of $68 \mathrm{mg}$ (0.09 mmol, 82\%); anal. calcd. for $\mathrm{C}_{36} \mathrm{H}_{38} \mathrm{~N}_{4} \mathrm{P}_{2} \mathrm{RuS}_{2}$ : exptl. (calcd.) C 57.24 (57.36), H 5.15 (5.08), N 7.56 (7.43), S $8.58(8.51) ;{ }^{31} \mathrm{P}\left\{{ }^{1} \mathrm{H}\right\} \mathrm{NMR}$ (161.98 MHz, $\left.\mathrm{CH}_{2} \mathrm{Cl}_{2} / \mathrm{D}_{2} \mathrm{O}\right) \delta 47.72$ (s); molar conductance/ $\left(\Omega^{-1} \mathrm{~cm}^{2} \mathrm{~mol}^{-1}, \mathrm{CH}_{2} \mathrm{Cl}_{2}, 1.0 \times 10^{-3} \mathrm{M}\right) 1.08 ; \mathrm{IR}(\mathrm{CsI}) \mathrm{v} / \mathrm{cm}^{-1}$ $(v \mathrm{C}-\mathrm{H}) 3114,3051,\left(\nu \mathrm{CH}_{2}\right) 2909,2851,(v \mathrm{C}=\mathrm{C} / \mathrm{C}=\mathrm{N}) 1590$, 1527, $(v \mathrm{~N}=\mathrm{C}+\delta \mathrm{CH}) 1434,(v-\mathrm{C}=\mathrm{C}($ ring $)+v \mathrm{C}=\mathrm{C}(\mathrm{dppb}))$ $1485,1296,(v \mathrm{C}=\mathrm{S}) 1282,(v \mathrm{C}-\mathrm{S}) 1143,\left(v \mathrm{C}-\mathrm{P}_{\text {ring }}\right) 1092$, (vC-P) 741, (vC-P) 515, (vRu-P) 518, 491, (vRu-S) 438, $(v \mathrm{Ru}-\mathrm{N}) 421$; UV-Vis $\left(\mathrm{CH}_{2} \mathrm{Cl}_{2}, 1.18 \times 10^{-5} \mathrm{M}\right) \lambda / \mathrm{nm}$ $\left(\varepsilon / \mathrm{M}^{-1} \mathrm{~cm}^{-1}\right) 236$ (75937), 276 (22842), 338 (4585).

\section{Complex 3 ([Ru(dmp) $\left.\left.)_{2}(\mathrm{dppb})\right]\right)$}

Yield of $80 \mathrm{mg}(0.10 \mathrm{mmol}, 90 \%)$; anal. calcd. for $\mathrm{C}_{36} \mathrm{H}_{38} \mathrm{~N}_{8} \mathrm{P}_{2} \mathrm{RuS}_{2}$ : exptl. (calcd.) C 53.06 (53.39), H 4.68 (4.73), N 13.68 (13.84), S 7.93 (7.92); ${ }^{31} \mathrm{P}\left\{{ }^{1} \mathrm{H}\right\}$ NMR (161.98 MHz, $\left.\mathrm{CH}_{2} \mathrm{Cl}_{2} / \mathrm{D}_{2} \mathrm{O}\right) \delta 48.54$ (s); molar conductance / $\left(\Omega^{-1} \mathrm{~cm}^{2} \mathrm{~mol}^{-1}, \mathrm{CH}_{2} \mathrm{Cl}_{2}, 1.0 \times 10^{-3} \mathrm{M}\right) 1.01$; IR $(\mathrm{CsI})$ $v / \mathrm{cm}^{-1}\left(v \mathrm{NH}_{2}\right) 3437,3394,(v \mathrm{C}-\mathrm{H}) 3127,3058,\left(v \mathrm{CH}_{2}\right)$ 2917, 2852, $(v \mathrm{C}=\mathrm{C} / \mathrm{C}=\mathrm{N}) 1619,1547,(v \mathrm{~N}=\mathrm{C}+\delta \mathrm{CH})$ 1434, $(v-\mathrm{C}=\mathrm{C}($ ring $)+v \mathrm{C}=\mathrm{C}(\mathrm{dppb}) 1485,1296,(v \mathrm{C}=\mathrm{S})$ 1312 , ( $v \mathrm{C}-\mathrm{S}) 1159,\left(v \mathrm{C}-\mathrm{P}_{\text {ring }}\right) 1091,(v \mathrm{C}-\mathrm{P}) 742,(v \mathrm{C}-\mathrm{P})$ 516, (vRu-P) 520, 491, (vRu-S) 460, (vRu-N) 430; UV-Vis $\left(\mathrm{CH}_{2} \mathrm{Cl}_{2}, 1.29 \times 10^{-5} \mathrm{M}\right) \lambda / \mathrm{nm}\left(\varepsilon / \mathrm{M}^{-1} \mathrm{~cm}^{-1}\right) 236$ (81960), 266 (29537), 334 (11287).

\section{Complex 4 ([Ru(mpca) $\left.\left.)_{2}(\mathrm{dppb})\right]\right)$}

Yield of $72 \mathrm{mg}$ (0.09 mmol, 78\%); anal. calcd. for $\mathrm{C}_{40} \mathrm{H}_{36} \mathrm{~N}_{2} \mathrm{O}_{4} \mathrm{P}_{2} \mathrm{RuS}_{2}$ : exptl. (calcd.) C 57.56 (57.48), $\mathrm{H} 4.51$ (4.34), N 3.13 (3.35), S 7.59 (7.67); ${ }^{31} \mathrm{P}\left\{{ }^{1} \mathrm{H}\right\}$ NMR (161.98 MHz, $\left.\mathrm{CH}_{2} \mathrm{Cl}_{2} / \mathrm{D}_{2} \mathrm{O}\right) \delta 50.04$ (s); molar conductance / $\left(\Omega^{-1} \mathrm{~cm}^{2} \mathrm{~mol}^{-1}, \mathrm{CH}_{2} \mathrm{Cl}_{2}, 1.0 \times 10^{-3} \mathrm{M}\right) 0.94 ; \mathrm{IR}(\mathrm{CsI}) \mathrm{v} / \mathrm{cm}^{-1}$ $(v \mathrm{C}-\mathrm{H}) 3152,3046,\left(v \mathrm{CH}_{2}\right) 2919,2849,(v \mathrm{COOH})$ 1683, $(v \mathrm{C}=\mathrm{C} / \mathrm{C}=\mathrm{N}) 1580,1538,(v \mathrm{~N}=\mathrm{C}+\delta \mathrm{CH}) 1434$, $(v-\mathrm{C}=\mathrm{C}($ ring $)+v \mathrm{C}=\mathrm{C}(\mathrm{dppb})) 1485,1296,(v \mathrm{C}=\mathrm{S}) 1264$, $(v \mathrm{C}-\mathrm{S})$ 1153, ( $\left.v \mathrm{C}-\mathrm{P}_{\text {ring }}\right)$ 1094, ( $\left.v \mathrm{C}-\mathrm{P}\right)$ 738, ( $\left.v \mathrm{C}-\mathrm{P}\right)$ 510, ( $v \mathrm{Ru}-\mathrm{P})$ 518, 491, ( $v \mathrm{Ru}-\mathrm{S})$ 442, ( $v \mathrm{Ru}-\mathrm{N})$ 420; UV-Vis $\left(\mathrm{CH}_{2} \mathrm{Cl}_{2}, 2.12 \times 10^{-5} \mathrm{M}\right) \lambda / \mathrm{nm}\left(\varepsilon / \mathrm{M}^{-1} \mathrm{~cm}^{-1}\right) 232$ (44083), 300 (20707), 356 (8020), 422 (7990).

\section{Cell culture, cytotoxicity assays}

Cytotoxicity assays in vitro using human tumor cell lines represent the standard method for screening of antitumor agents. Therefore, to assess their pharmacological properties, the ruthenium compounds were assayed against the human breast tumor cell lines MCF-7 (ATCC No. HTB-22) and MDA-MB-231 (ATCC No. HTB-26), the human lung tumor line, A549 (ATCC No. CCL-185), the human prostate DU-145(ATCC No. HTB-81), the 
human hepatocellular carcinoma HepG2 (purchased from the Rio de Janeiro Cell Bank, Brazil), and Homo sapiens lung normal, MRC-5 (ATCC No. CCL-171). The cells were routinely maintained with Dulbecco's Modified Eagle's medium (DMEM-for HepG2, A549 and MRC-5) or RPMI 1640 (for MCF-7 and DU-145) supplemented with $10 \%$ fetal bovine serum (FBS), at $37^{\circ} \mathrm{C}$ in a humidified $5 \% \mathrm{CO}_{2}$ atmosphere. For the cytotoxicity assay, $1.5 \times 10^{4}$ cells in $150 \mu \mathrm{L}$ of complete medium were added to each well on 96-wellplates (Corning Costar, Merk KGaA, Darmstadt, Germany). The complexes were dissolved in sterile dimethyl sulfoxide (DMSO) (from 20 to $0.0006 \mathrm{mM}$ ). Then, $0.75 \mu \mathrm{L}$ of each complex sample was added to $150 \mu \mathrm{L}$ of biological medium. At the end, the concentration of DMSO in the solution was $0.1 \%$. Cells were exposed to the complex for a $48 \mathrm{~h}$ period. The conversion of 3-(4,5-dimethylthiazol-2-yl)-2,5-diphenyltetrazoline bromide (MTT) to formazan by cells metabolically viable was analyzed by automated microplate reader at $540 \mathrm{~nm}$. The cell viability percentage was calculated by dividing the average absorbance of treated cells by that of the control; drug concentration (logarithmic scale) versus percentage of cell viability was plotted to determine the $\mathrm{IC}_{50}$ (drug concentration at which $50 \%$ of the cells are viable relative to the control), with its estimated error derived from the average of 3 trials.

\section{Partition coefficient $(P)$}

Water-octanol partition coefficients were determined using the stir flask method. ${ }^{25}$ Each complex was tested in a mixture of equal volumes of water and $n$-octanol with continuous shaking for $24 \mathrm{~h}$ at $1000 \mathrm{rpm}$ and $37^{\circ} \mathrm{C}$. Then the samples were centrifuged for $5 \mathrm{~min}$ at $300 \mathrm{rpm}$ and the organic and aqueous phases were separated. The concentration of drug in each phase was measured spectrophotometrically in order to determine values of $\log \mathrm{P}=$ [drug] (in $n$-octanol) / [drug] (in water). The experiments were carried out in triplicate.

\section{Interaction studies with DNA}

\section{Viscosity experiments}

The viscosity measurements were successfully used to determine intercalation or non-intercalation binding modes of complexes to DNA. ${ }^{26}$ Viscosity measurements were carried out using an Ostwald viscometer immersed in a water bath maintained at $25^{\circ} \mathrm{C}$. The DNA concentration in buffer Tris-HCl was kept constant in all samples, while the complex concentration was increased from 0 to $60 \mu \mathrm{M}$. The flow time was measured at least 5 times with a digital stopwatch and the mean value was calculated. Data are presented as $\left(\eta / \eta_{0}\right)^{1 / 3}$ versus the [complex] / [DNA] ratio, where $\eta$ and $\eta_{0}$ are the specific viscosities of DNA in the presence and absence of the complex, respectively. The values of $\eta$ and $\eta_{0}$ were calculated using the expression $\left(t-t_{b}\right) / t_{b}$, where $t$ is the observed flow time and $t_{b}$ is the flow time of the buffer alone.

\section{Interaction study by square-wave voltammetry (SWV)}

In SWV, a three-electrode system was used, in which a glassy carbon was used as a working electrode (CG), $\mathrm{Ag} / \mathrm{AgCl}$ as a reference electrode and platinum plate as a counter-electrode. The interaction studies were carried out in a Tris-HCl buffer ( $\mathrm{pH} 7.4) / 30 \%$ DMSO. The titration was performed by adding $30 \mu \mathrm{L}$ aliquots of calf thymus DNA (ct-DNA, $4.5 \mathrm{mM}$ ) to an electrochemical cell, containing $2.0 \mathrm{~mL}$ of $1.0 \mu \mathrm{M}$ complex solution. ${ }^{27,28}$

\section{Agarose gel electrophoresis studies}

For this study, the following was used: $1 \mu \mathrm{L}$ aliquots of pBlue-Script KSII(+) plasmid DNA in $28 \mu \mathrm{L}$ Tris-HCl buffer, which were incubated at $37^{\circ} \mathrm{C}$ for $20 \mathrm{~h}$ with $1 \mu \mathrm{L}$ different concentrations of the complexes. After incubation, $20 \mu \mathrm{L}$ of each sample was analyzed by electrophoresis in a $1 \%$ agarose gel overnight at $30 \mathrm{~V}$, using Tris-borate-EDTA buffer (TBE) and stained with ethidium bromide ( $5 \mu \mathrm{L}$ ethidium bromide per $50 \mathrm{~mL}$ agarose gel mixture). Free DNA and DNA + DMSO samples were used as controls. The DNA bands were visualized by imaging with UV light transilumination (ChemiDocMP, Bio-Rad, Hercules, California, USA).

\section{Topoisomerase IB assays}

\section{Purification of human topoisomerase IB}

Human topoisomerase IB was expressed by the galactose inducible promoter in a multi-copy plasmid, YCpGAL1-e-wild type and YCpGAL1-e-Y723F, used for the transformation of EKY3 cells, as described previously. ${ }^{29}$ The epitope-tagged constructs contain the N-terminal sequence FLAG: DYKDDDY (indicated with "e"), recognized by the M2monoclonal antibody. Purification was carried out using an ANTI-FLAG M2 affinity gel column (Sigma-Aldrich, Saint Louis, Missouri, USA). The FLAG-fusion topoisomerase IB was eluted by competition with five column volumes of a solution containing a $100 \mu \mathrm{g} \mathrm{mL}^{-1}$ FLAG peptide in $50 \mathrm{mM}$ Tris- $\mathrm{HCl}$ and $150 \mathrm{mM} \mathrm{KCl}, \mathrm{pH}$ 7.4. Glycerol was added to each fraction up to a final concentration of $40 \%$. All the fractions were stored at $-20{ }^{\circ} \mathrm{C}$. Integrity of the protein was verified by the immunoblot assay. The purified protein was resolved in 
sodium dodecyl sulfate, polyacrylamide gel electrophoresis (SDS-PAGE), transferred to a nitrocellulose membrane and immunoblotted with a specific monoclonal antibody (Sigma-A9469). An immunoreactive band, corresponding to topoisomerase I, was detected with the BCIP/NBT substrate (Sigma-B3804).

\section{DNA relaxation assay}

The activity of TopIB was assayed in $30 \mathrm{~mL}$ of reaction volume containing $0.5 \mathrm{mg}$ of negatively supercoiled pBlue-Script KSII(+) and reaction buffer $(20 \mathrm{mM}$ Tris- $\mathrm{HCl}, 0.1 \mathrm{mM}$ EDTA, $10 \mathrm{mM} \mathrm{MgCl}_{2}, 50 \mu \mathrm{g} \mathrm{mL}$ acetylated-BSA (acetylated-bovine serum albumin) and $150 \mathrm{mM} \mathrm{KCl}, \mathrm{pH}$ 7.4). The effects of 1-4 enzyme activity were studied by adding increasing concentrations of the complexes in a range of 0.75 to $300 \mu \mathrm{M}$. Reactions were stopped with a final concentration of $0.5 \%$ SDS. Samples were electrophoresed in $1 \%$ agarose gel in $50 \mathrm{mM}$ Tris, $45 \mathrm{mM}$ boric acid, and $1 \mathrm{mM}$ ethylenediaminetetraacetic acid (EDTA). The gel was stained with ethidium bromide $\left(5 \mu \mathrm{g} \mathrm{mL} \mathrm{m}^{-1}\right)$, destained with water and photographed under UV illumination. The enzyme and the inhibitor were pre-incubated at $37^{\circ} \mathrm{C}$ for $5 \mathrm{~min}$, before adding the DNA substrate. Assays were performed at least three times, but only one representative gel is shown.

\section{Cleavage kinetics}

The oligonucleotide CL14(5'-GAAAAAAGA CTTAG-3'), radiolabelled with [ $\left.\gamma^{-32} \mathrm{P}\right]$ ATP at its 5' end, and the CP25 complementary strand ( 5 ' - TAAAAATTTTTCTAAGTCTTTTTTC-3'), phosphorylated at its 5' end, with unlabeled ATP, were annealed at a 2-fold molar excess of CP25 over CL14, creating the so-called "suicide substrate", which contains only a partial duplex. The suicide cleavage reactions were carried out incubating $20 \mathrm{nM}$ suicide substrate with the enzyme in a reaction buffer at $37{ }^{\circ} \mathrm{C}$ and in the presence of $50 \mu \mathrm{M}$ complex 2 . DMSO was added to no-drug control. Before adding the enzyme, a $5 \mu \mathrm{L}$ sample of the reaction mixture was removed and used as control. At different time points, $5 \mu \mathrm{L}$ aliquots were removed and the reactions stopped with $0.5 \%$ SDS. Afterwards, the ethanol precipitation samples were re-suspended in $6 \mu \mathrm{L}$ of $1 \mu \mathrm{g} \mathrm{mL} L^{-1}$ trypsin and incubated at $37^{\circ} \mathrm{C}$ for $1 \mathrm{~h}$. Samples were analyzed using denaturing urea/poly acrylamide gel electrophoresis.

\section{Reconnection kinetics}

A suicide CL14/CP25 substrate (20 nM), prepared as above, was incubated with the topoisomerase IB enzyme for $30 \mathrm{~min}$ at $37{ }^{\circ} \mathrm{C}$ in reaction buffer. A $5 \mu \mathrm{L}$ aliquot of the reaction mixture was removed and used as the zero time point. Reconnection reactions were initiated by adding a 200-fold molar excess of R11 oligonucleotide (5'-AGAAAAATTTT-3') over the duplex CL14/CP25 in the presence or the absence of $50 \mu \mathrm{M}$ complex 2 . At different times, $5 \mu \mathrm{L}$ aliquots were removed and the reactions were stopped with $0.5 \%$ SDS. After ethanol precipitation samples were re-suspended in $5 \mu \mathrm{L}$ of $1 \mu \mathrm{g} \mathrm{mL} \mathrm{L}^{-1}$ trypsin and incubated at $37^{\circ} \mathrm{C}$ for $1 \mathrm{~h}$. Samples were analyzed by denaturing urea/polyacrylamide gel electrophoresis. The experiment was replicated three times and a representative gel is shown.

\section{Results and Discussion}

\section{Characterization}

Complexes 1-4 were synthesized from the $\left[\mathrm{RuCl}_{2}(\mathrm{dppb})\right.$ $\left.\left(\mathrm{PPh}_{3}\right)\right]$ precursor, by varying the $\mathrm{N}-\mathrm{S}$ chelating ligand, as summarized in Scheme 1.

The conductivity measurements of complexes 1-4 were performed in $\mathrm{CH}_{2} \mathrm{Cl}_{2}$, and the results of 0.96, 1.08, 1.01 and $0.94 \mathrm{~S} \mathrm{~m}^{2} \mathrm{~mol}^{-1}$, respectively, indicate that the complexes are neutral $\left(\mathrm{CH}_{2} \mathrm{Cl}_{2}\right.$ range 1:1 $\left.=12-77 \mathrm{~S} \mathrm{~m}^{2} \mathrm{~mol}^{-1}\right){ }^{30}$ The UV-Vis absorption spectra in solutions of $\mathrm{CH}_{2} \mathrm{Cl}_{2}$ for the complexes (see Supplementary Information (SI) section, Figure S1 and Table S2) are characterized by intense high energy bands in the range of 232-300 nm, which can be assigned to ligand-localized, intra-ligand $\pi-\pi^{*}$ transition. Moreover, the complexes exhibit lower-energy bands in the range of 304-422 nm, which can be assigned as metal to ligand charge transfer (MLCT) transition, $\mathrm{Ru}(\mathrm{d} \pi)$ to ligand $\left(\pi^{*}\right)$. The cyclic voltammetry experiments of complexes 1-4, carried out in $\mathrm{CH}_{2} \mathrm{Cl}_{2}$ solutions, presented a quasi-reversible process, corresponding to one-electron $\mathrm{Ru}^{\mathrm{II}} / \mathrm{Ru}^{\mathrm{III}}$, with half-wave potential, $\mathrm{E}_{1 / 2}$, values of $582 \mathrm{mV}$ (anodic peak potential $($ Epa $)=733 \mathrm{mV}$ and cathodic peak potential $(\mathrm{Epc})=431 \mathrm{mV})$ for $\mathbf{1}, 323 \mathrm{mV}(\mathrm{Epa}=389 \mathrm{mV}$ and $\mathrm{Epc}=257 \mathrm{mV})$ for 2, $422 \mathrm{mV}(\mathrm{Epa}=544 \mathrm{mV}$ and $\mathrm{Epc}=300 \mathrm{mV})$ for 3 and $572 \mathrm{mV}($ Epa $=625 \mathrm{mV}$ and Epc $=519 \mathrm{mV}$ ) for 4 . The electrochemical behavior of complex 1-4, in cyclic voltammetric experiments, was similar to that found for other ruthenium compounds reported in the literature, such as the $\left[\mathrm{Ru}(\mathrm{SpymMe} 2-\mathrm{N}, \mathrm{S})_{2}(\mathrm{dppb})\right]$, where a quasi-reversible one-electron $\mathrm{Ru}^{\mathrm{II}} / \mathrm{Ru}^{\mathrm{III}}$ redox process was observed, with $\mathrm{E}_{1 / 2}=432 \mathrm{mV}(\mathrm{Epa}=495 \mathrm{mV}$ and $\mathrm{Epc}=369 \mathrm{mV}) .{ }^{31}$ Complex 2 shows an oxidation process at $787 \mathrm{mV}$ in its cyclic voltammogram, which belongs to the oxidation of the coordinated 2-mercapto1-methyl-imidazole ligand, in comparison with the process at $813 \mathrm{mV}$ in the free ligand (see Figure S2, SI section). 
<smiles>ClP(CP(c1ccccc1)(c1ccccc1)(c1ccccc1)c1ccccc1)(c1ccccc1)(c1ccccc1)c1ccccc1</smiles>

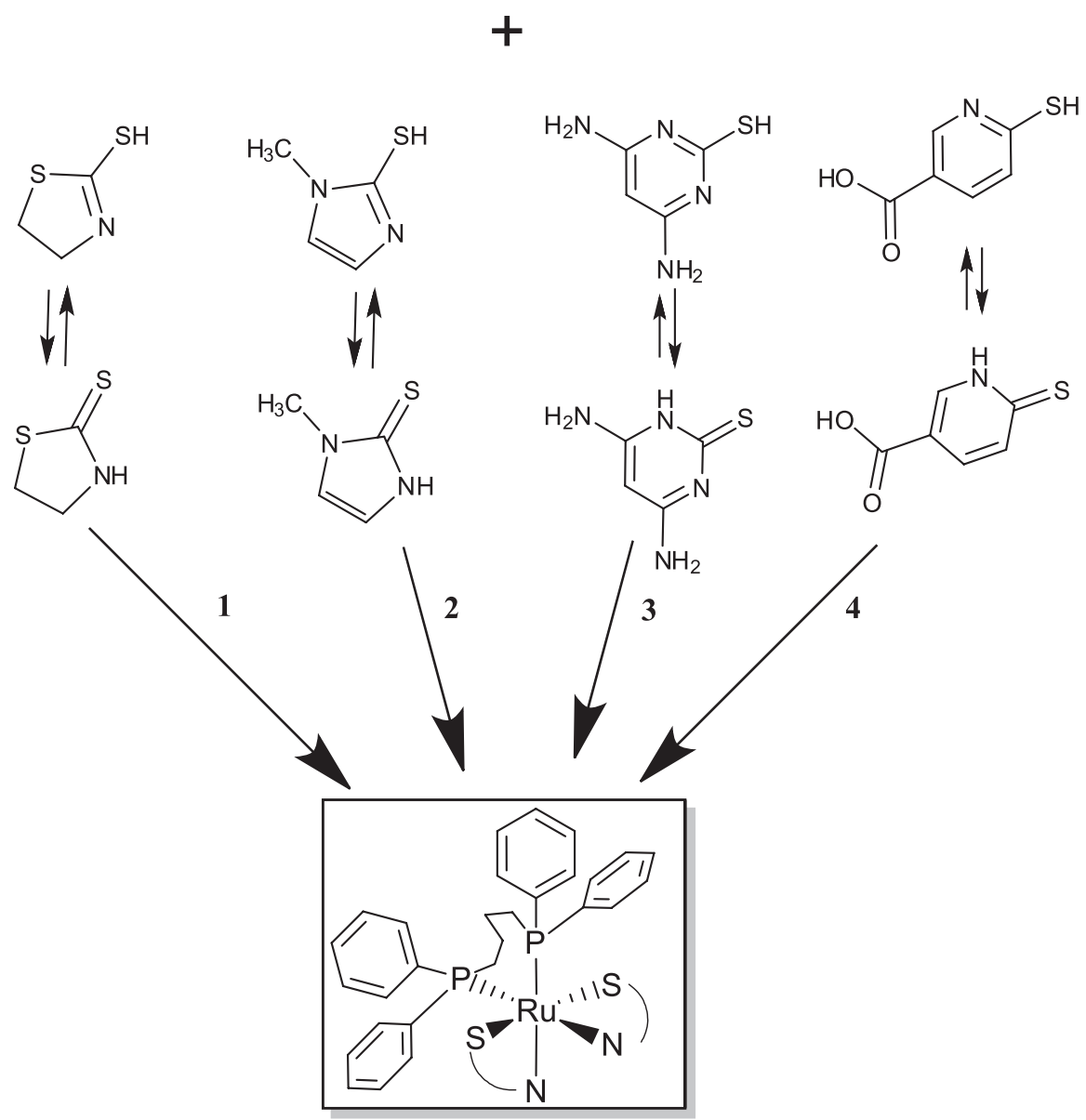

Scheme 1. Routes used to prepare the complexes: in $\mathrm{CH}_{2} \mathrm{Cl}_{2}$, stirring for $12 \mathrm{~h}$ at room temperature; triethylamine was used to deprotonate the ligands.

The IR spectra of the new complexes also confirm the presence of the ligands coordinated to the ruthenium. The band, assigned to the $v(\mathrm{~N}-\mathrm{H})$ stretch vibration at $3200-3100 \mathrm{~cm}^{-1}$ in the free ligands, is absent in the complexes 1-4, indicating that the ligands are coordinated in the deprotonated form. ${ }^{32}$ In the complexes, the bands related to $\mathrm{v} \mathrm{C}-\mathrm{S}$ and $\delta \mathrm{C}-\mathrm{S}$ absorptions of ligands occur in the regions around 1312-1264 and 742-738 $\mathrm{cm}^{-1}$, respectively (see Figure S4 and Table S3, SI section). ${ }^{33}$

The ${ }^{31} \mathrm{P}\left\{{ }^{1} \mathrm{H}\right\}$ NMR spectra of the complexes, in $\mathrm{CD}_{2} \mathrm{Cl}_{2}$, present a singlet signal with chemical shifts at $52.88 \mathrm{ppm}$ for $\mathbf{1} ; 47.72 \mathrm{ppm}$ for $\mathbf{2} ; 48.54 \mathrm{ppm}$ for $\mathbf{3}$ and $50.04 \mathrm{ppm}$ for $\mathbf{4}$, indicating the chemical and magnetic equivalence of the two phosphorus atoms of the dppb ligand. The stability of the compounds in the biological medium (DMEM + 30\% DMSO) was supported by ${ }^{31} \mathrm{P}\left\{{ }^{1} \mathrm{H}\right\}$ NMR experiments in which solutions of 1-4 were left to stand for at least $72 \mathrm{~h}$ at room temperature, and no changes were observed in their spectra (see Figure S5, SI section).

The ${ }^{1} \mathrm{H}$ NMR spectra of 1-4 showed signals of hydrogens for the phosphine phenyl groups as a series of multiplets in the $\delta 7.50-6.60 \mathrm{ppm}$ region, corresponding to 20 hydrogen atoms. The hydrogen atoms of the aromatic rings of biphosphine appear in the same region as the spectrum, making a more detailed assignment difficult, due to the overlapping of signals. However, even if it was not possible 
to assign all the signals of the hydrogen atoms, it was possible to obtain the values of the integrals corresponding to the expected structures, which were omitted for the sake of clarity. There are broad multiplets in the ${ }^{1} \mathrm{H}$ NMR spectra of the complexes at about 1.5 and $2.7 \mathrm{ppm}$ corresponding to $4 \mathrm{H}$ each, from the $\mathrm{CH} 2-(\mathrm{CH} 2)_{2}-\mathrm{CH} 2$ hydrogens, belonging to the dppb ligand. ${ }^{22}$ The absence of the signal from the $-\mathrm{SH}$ group in the ${ }^{1} \mathrm{H}$ NMR spectra of the complexes confirm the coordination of the mecapto ligands to the metal through the sulfur atoms. The other hydrogen signals from the mercapto molecules are in a different region depending on the ligand. The groups of signals of the hydrogen atoms (aliphatic and aromatic) can be visualized with greater clarity in the contour map of correlation spectroscopy (COSY) $\left({ }^{1} \mathrm{H}-{ }^{-} \mathrm{H}\right)$, where it is possible to observe the couplings of the neighboring hydrogen atoms. The coordination of the ligands was verified by characteristic signals in different region of their spectra, depending on the ligand. In the ${ }^{13} \mathrm{C}\left\{{ }^{1} \mathrm{H}\right\}$ NMR and heteronuclear single quantum coherence spectroscopy (HSQC ${ }^{1} \mathrm{H}^{-13} \mathrm{C}$ ) spectra of the complexes, the signals for the carbon atoms of the $\mathrm{N}, \mathrm{S}$ ligands were observed indicating the coordination of the ligand to the $\mathrm{Ru}^{\mathrm{II}}$ metal center (see Figure S9, SI section).

The crystalline structures were determined for all four complexes (Figure 1), confirming the previously proposed coordination modes for the system. The crystalline structures of the complexes presented slightly distorted octahedral geometries, characteristic of heteroleptic monoclinic complexes (1 and $\mathbf{3})$ and triclinic (2 and $\mathbf{4})$, in the space groups $\mathrm{P} 2_{1 / \mathrm{n}}(\mathbf{1}), \mathrm{C} 2 / \mathrm{c}(\mathbf{3})$ and $\mathrm{P} \overline{1}(\mathbf{2}$ and $\mathbf{4})$. The N,S donor ligands coordinate bidentate to the metal center, with the nitrogen atoms located trans to the phosphorus atoms and the sulfur atoms trans positioned to each other. The refinement data of the structures are shown in Table $\mathrm{S} 1$. The values of distances $(\AA)$ and binding angles $\left({ }^{\circ}\right)$ are shown in Table 1 , and are in agreement with data from other $\mathrm{Ru}^{\mathrm{II}}$ complexes containing two N,S type ligands and biphosphinic ligands found in the literature. The bond lengths for the complexes are in the range found for other ruthenium/phosphine/mercapto compounds: $\mathrm{Ru}-\mathrm{P}(2.254-2.277 \AA)$; Ru-S (2.406-2.448 $\mathrm{A}$ ) and $\mathrm{Ru}-\mathrm{N}$ (2.151-2.187 $\mathrm{A})$. The $\mathrm{C}-\mathrm{S}$ bond distances in the complexes (from 1.720 to $1.753 \AA$ ) are longer than expected for a double bond $(\mathrm{C}=\mathrm{S}: 1.62 \AA)$ and shorter than a single bond (C-S: $1.81 \AA$ ), suggesting a partial double bond character, where the sulfur atom is negatively charged. ${ }^{31,32}$

\section{Cytotoxicity assays and partition coefficient $(\log \mathrm{P})$}

To assess the cytotoxic activity of complexes, the cell viability was determined by the MTT test, a colorimetric
Table 1. Selected bond lengths and angles for 1, 2,3 and 4

\begin{tabular}{|c|c|c|c|c|}
\hline Bond length / $\AA$ & 1 & 2 & 3 & 4 \\
\hline $\mathrm{Ru}-\mathrm{P}(1)$ & $2.2537(8)$ & $2.258(2)$ & $2.265(2)$ & $2.265(1)$ \\
\hline $\mathrm{Ru}-\mathrm{P}(2)$ & $2.2688(8)$ & $2.268(2)$ & $2.269(2)$ & $2.277(1)$ \\
\hline $\mathrm{Ru}-\mathrm{N}(11)$ & $2.183(3)$ & $2.186(5)$ & $2.187(5)$ & $2.163(3)$ \\
\hline $\mathrm{Ru}-\mathrm{N}(21)$ & $2.151(3)$ & $2.162(4)$ & $2.161(5)$ & $2.165(3)$ \\
\hline $\mathrm{Ru}-\mathrm{S}(11)$ & $2.4261(8)$ & $2.435(2)$ & $2.444(2)$ & $2.411(1)$ \\
\hline $\mathrm{Ru}-\mathrm{S}(21)$ & $2.4476(8)$ & $2.461(2)$ & $2.406(2)$ & $2.430(1)$ \\
\hline $\mathrm{C}-\mathrm{S}(11)$ & $1.747(3)$ & $1.724(6)$ & $1.738(7)$ & $1.720(4)$ \\
\hline $\mathrm{C}-\mathrm{S}(21)$ & $1.753(3)$ & $1.743(7)$ & $1.727(6)$ & $1.726(4)$ \\
\hline Angle / degree & 1 & 2 & 3 & 4 \\
\hline $\mathrm{N}(21)-\mathrm{Ru}-\mathrm{N}(11)$ & $82.99(10)$ & $84.59(17)$ & $84.05(19)$ & $79.25(11)$ \\
\hline $\mathrm{N}(21)-\mathrm{Ru}-\mathrm{P}(1)$ & $91.53(7)$ & $91.33(13)$ & $93.41(15)$ & $94.29(8)$ \\
\hline $\mathrm{N}(11)-\mathrm{Ru}-\mathrm{P}(1)$ & $167.26(7)$ & $170.16(14)$ & $170.19(13)$ & $166.98(8)$ \\
\hline $\mathrm{N}(21)-\mathrm{Ru}-\mathrm{P}(2)$ & $167.39(7)$ & $170.36(14)$ & $164.60(13)$ & $165.58(9)$ \\
\hline $\mathrm{N}(11)-\mathrm{Ru}-\mathrm{P}(2)$ & $91.85(7)$ & $90.79(13)$ & $92.65(14)$ & $93.20(8)$ \\
\hline $\mathrm{P}(1)-\mathrm{Ru}-\mathrm{P}(2)$ & $95.72(3)$ & $94.51(5)$ & $92.21(6)$ & $95.39(4)$ \\
\hline $\mathrm{N}(21)-\mathrm{Ru}-\mathrm{S}(11)$ & $91.23(7)$ & $90.56(15)$ & $100.17(13)$ & $93.43(9)$ \\
\hline $\mathrm{N}(11)-\mathrm{Ru}-\mathrm{S}(11)$ & $67.16(7)$ & $68.74(14)$ & $66.03(13)$ & $67.29(9)$ \\
\hline $\mathrm{P}(1)-\mathrm{Ru}-\mathrm{S}(11)$ & $101.62(3)$ & $102.43(5)$ & $105.27(6)$ & $102.16(4)$ \\
\hline $\mathrm{P}(2)-\mathrm{Ru}-\mathrm{S}(11)$ & $97.38(3)$ & $95.65(6)$ & $92.14(6)$ & $94.93(4)$ \\
\hline $\mathrm{N}(21)-\mathrm{Ru}-\mathrm{S}(21)$ & $66.53(6)$ & $68.20(15)$ & $67.03(13)$ & $66.50(9)$ \\
\hline $\mathrm{N}(11)-\mathrm{Ru}-\mathrm{S}(21)$ & $98.77(7)$ & $94.55(14)$ & $98.84(13)$ & $97.75(9)$ \\
\hline $\mathrm{P}(1)-\mathrm{Ru}-\mathrm{S}(21)$ & $89.49(3)$ & $92.24(6)$ & $88.83(6)$ & $89.87(4)$ \\
\hline $\mathrm{P}(2)-\mathrm{Ru}-\mathrm{S}(21)$ & $103.14(3)$ & $103.85(6)$ & $98.80(6)$ & $102.85(4)$ \\
\hline$S(11)-R u-S(21)$ & $155.57(3)$ & $154.59(6)$ & $161.85(6)$ & $157.52(4)$ \\
\hline
\end{tabular}

assay determined by the mitochondrial-dependent reduction of the soluble yellow tetrazolium salt to blue formazan crystals. The results obtained using these assays are listed in Table 2 (see the $\mathrm{IC}_{50}$ graphics in Figure S11, SI section). All four ligands used in this work were inactive against the tumor cells tested, showing $\mathrm{IC}_{50}>200 \mu \mathrm{M}$.

All complexes showed cytotoxic activity in cell lines studied, except for complex $\mathbf{1}$. These findings encouraged us to study the activity of the complexes in more depth in order to evaluate their interaction with different systems, such as DNA and topoisomerase, and to shed more light elucidate on their possible mechanism of action.

Lipophilicity or partition coefficient is usually expressed by $\log \mathrm{P}$, which describes the equilibrium between water and an immiscible lipid-like organic solvent, for example $n$-octanol. $\log \mathrm{P}$ is the ratio of concentrations in the two phases (log $\mathrm{P}=[\mathrm{drug}]($ in octanol) $/[\mathrm{drug}]($ in water)), so that a positive value for $\log \mathrm{P}$ reflects a preference for the lipid phase, and a negative value reflects the relative affinity of the complex for water. ${ }^{35}$ Complexes 1-4 showed 

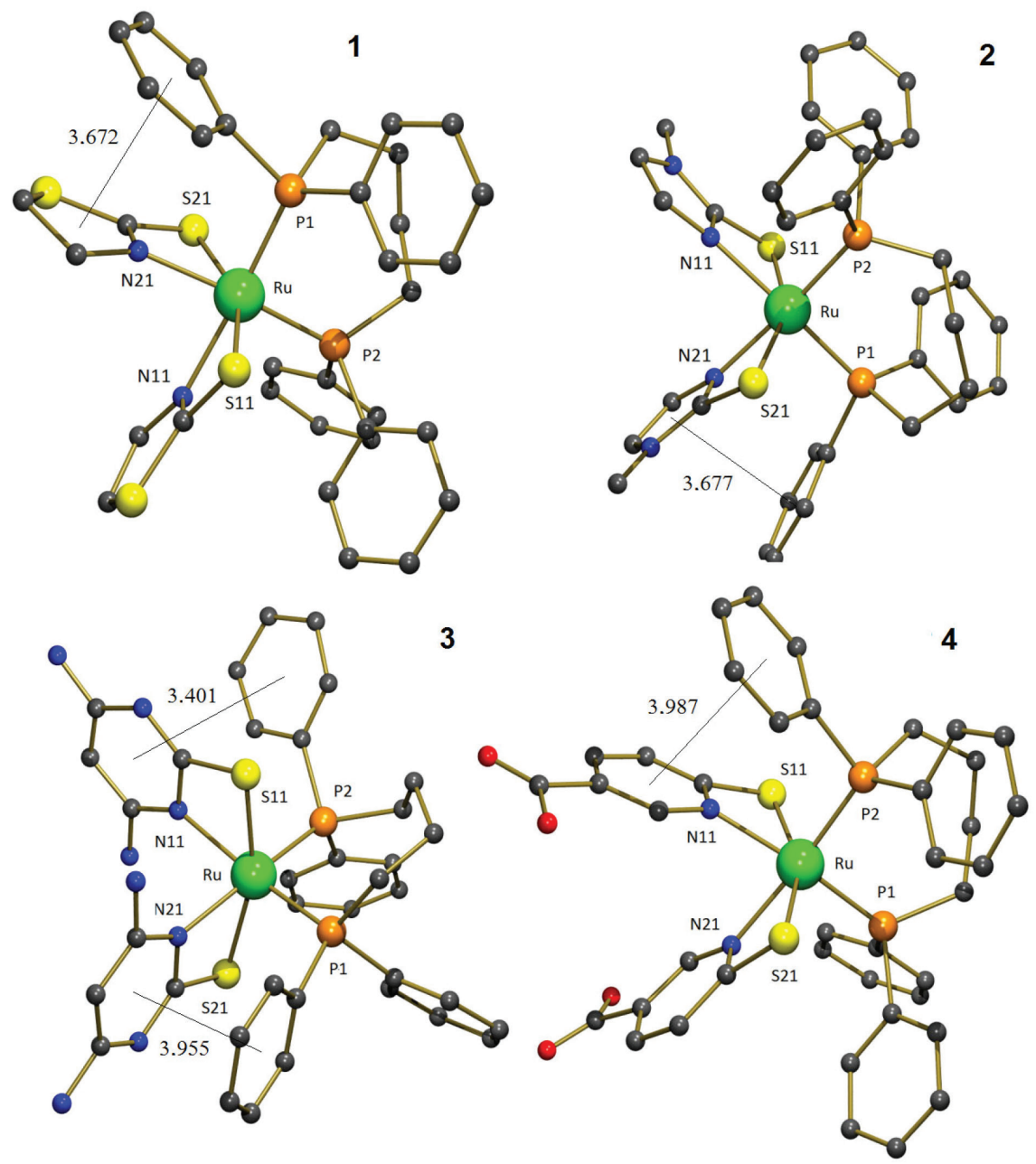

Figure 1. X-ray structures defined for complexes 1-4. Distances between centroids of rings are shown as fine lines. Hydrogen atoms were omitted for clarity.

Table 2. $\mathrm{IC}_{50} \pm \mathrm{SEM}$ values for cytotoxic activity of the complexes in tumor versus normal cell lines

\begin{tabular}{|c|c|c|c|c|c|c|}
\hline & \multicolumn{6}{|c|}{$\mathrm{IC}_{50} \pm \mathrm{SEM} / \mu \mathrm{M}$} \\
\hline & 1 & 2 & 3 & 4 & Precursor $^{\mathrm{a}}$ & Cisplatin \\
\hline MDA-MB-231 & $>200$ & $8.73 \pm 0.36$ & $10.43 \pm 0.79$ & $22.59 \pm 0.10$ & $22.85 \pm 0.95$ & $2.44 \pm 0.39$ \\
\hline MCF-7 & $>200$ & $12.10 \pm 0.38$ & $23.92 \pm 0.56$ & $24.47 \pm 1.56$ & $38.52 \pm 0.68$ & $13.98 \pm 2.02$ \\
\hline DU-145 & $>200$ & $3.26 \pm 0.17$ & $19.10 \pm 1.50$ & $35.57 \pm 1.75$ & $40.04 \pm 0.78$ & $2.33 \pm 0.40$ \\
\hline A549 & $>200$ & $8.80 \pm 1.44$ & $15.89 \pm 1.26$ & $25.06 \pm 0.29$ & $19.13 \pm 0.83$ & $14.40 \pm 1.45$ \\
\hline HepG2 & $>200$ & $2.52 \pm 1.08$ & $52.92 \pm 1.59$ & $44.30 \pm 1.54$ & $49.00 \pm 0,52$ & $16.31 \pm 0.74$ \\
\hline MRC-5 & $>200$ & $25.05 \pm 0.36$ & $57.79 \pm 0.85$ & $47.00 \pm 0.61$ & $15.46 \pm 0.82$ & $29.09 \pm 0.79$ \\
\hline $\mathrm{SI}^{\mathrm{b}}$ & - & 2.82 & 5.54 & 2.09 & 0.68 & 11.92 \\
\hline $\mathrm{SI}^{\mathrm{c}}$ & - & 2.07 & 2.87 & 1.92 & 0.40 & 2.08 \\
\hline $\mathrm{SI}^{\mathrm{d}}$ & - & 7.68 & 3.02 & 1.32 & 0.39 & 12.48 \\
\hline $\mathrm{SI}^{\mathrm{e}}$ & - & 2.85 & 3.64 & 1.87 & 0.81 & 2.02 \\
\hline $\mathrm{SI}^{\mathrm{f}}$ & - & 9.94 & 1.09 & 1.06 & 0.31 & 1.78 \\
\hline $\log \mathrm{P}$ & $0.34 \pm 0.10$ & $0.41 \pm 0.07$ & $0.40 \pm 0.12$ & $0.66 \pm 0.08$ & $0.63 \pm 0.04$ & $-2.21 \pm 0.06^{34}$ \\
\hline
\end{tabular}

aPrecursor: $\left[\mathrm{RuCl}_{2}(\mathrm{dppb})\left(\mathrm{PPh}_{3}\right)\right]$. ${ }^{\mathrm{b}} \mathrm{SI}=\mathrm{IC}_{50} \mathrm{MRC}-5 / \mathrm{IC}_{50} \mathrm{MDA}-\mathrm{MB}-\mathrm{S} 31 ;{ }^{\mathrm{c}} \mathrm{IS}=\mathrm{IC}_{50} \mathrm{MRC}-5 / \mathrm{IC}_{50} \mathrm{MCF}-7$; ${ }^{\mathrm{d} I S}=\mathrm{IC}_{50} \mathrm{MRC}-5 / \mathrm{IC}{ }_{50} \mathrm{DU}-145$; ${ }^{\mathrm{e}} \mathrm{SI}=\mathrm{IC}_{50} \mathrm{MRC}-5 / \mathrm{IC}_{50} \mathrm{~A} 549$; ${ }_{\mathrm{fS}}=\mathrm{IC}_{50} \mathrm{MRC}-5 / \mathrm{IC}_{50} \mathrm{HepG}$. IC $\mathrm{IC}_{50}$ : half maximal inhibitory concentration; SEM: standard error of measurement; MDA-MB-231: breast cancer cells, invasive; MCF-7: breast cancer cells, non-invasive; DU-145: human prostate cancer cell; A549: human lung tumor line; HepG2: human hepatocellular carcinoma; MRC-5: human lung normal cells; SI: selectivity index. 
$\log \mathrm{P}$ positive, suggesting their preference for the lipid phase permeation across biological membranes. However is not a condition of the compound to be lipophilic for it to be cytotoxic, as is well know that cisplatin, for example, becomes activated after it enters the cell.

\section{Interaction studies with DNA}

Viscosity measurements were used successfully to determine intercalation or non-intercalation binding modes of the complexes to DNA. The viscosity analysis of ct-DNA-binding revealed that viscosity does not change significantly when the concentration of a $\mathrm{Ru}^{\mathrm{II}}$ complex increases (see Figure 2). It is well known that classical intercalators, such as ethidium bromide, lead to an increase in the viscosity of ct-DNA, when in the presence of complexes, because separation of the base pairs occurs to accommodate the intercalator. ${ }^{36} \mathrm{~A}$ covalent DNA-binding mode may cause its fragmentation, thus decreasing the DNA viscosity. No significant change indicates that complexes 1-4 bind with DNA in a non-intercalative and non-covalent manner.
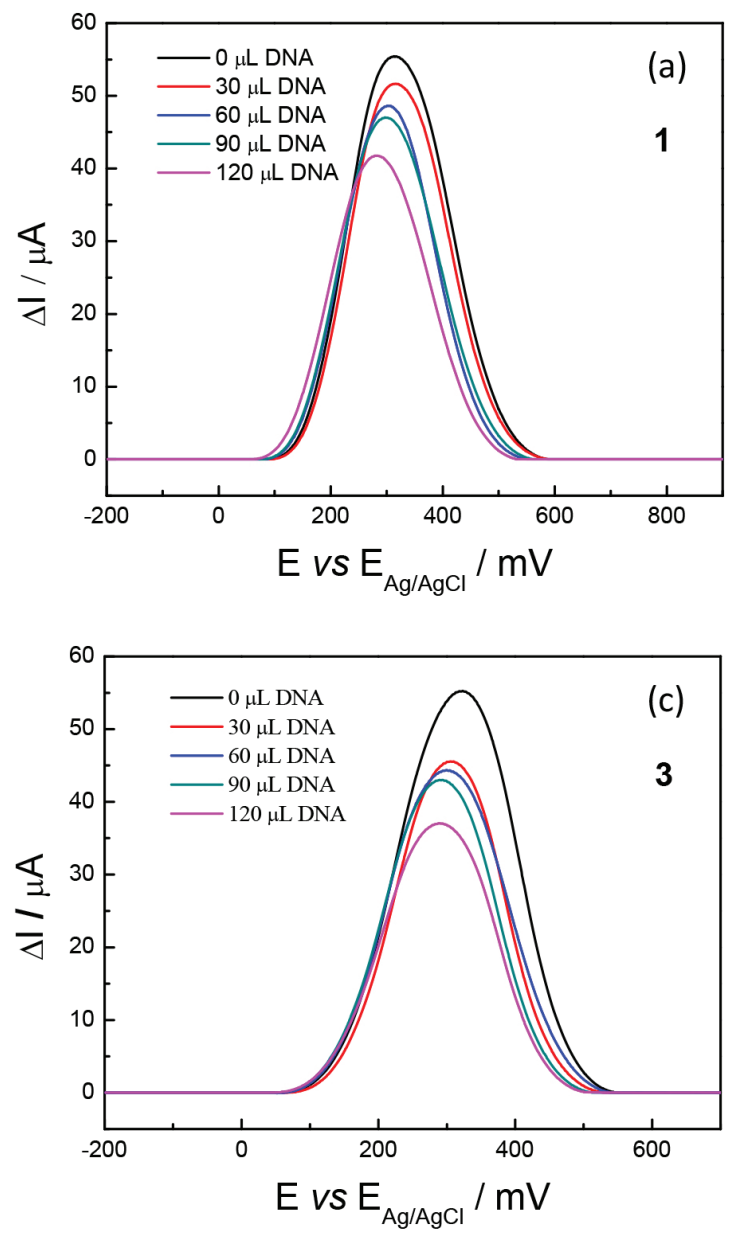

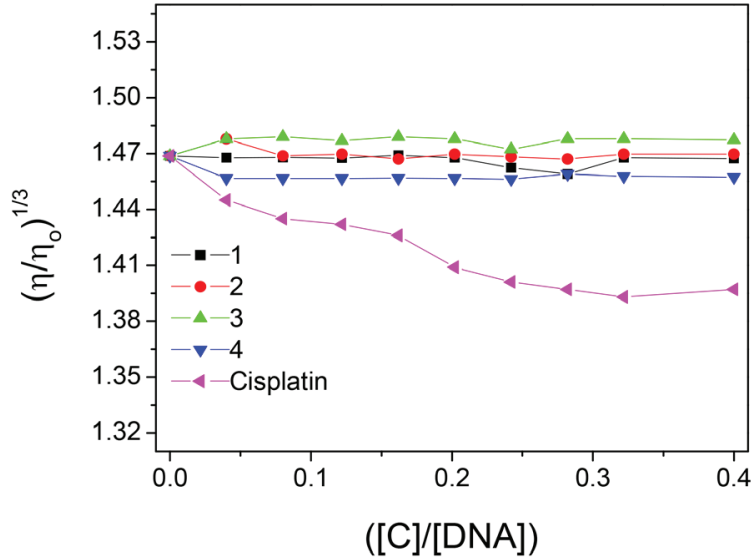

Figure 2. Viscosity of CT-DNA $\left(\eta / \eta_{0}\right)^{1 / 3}$, increasing the complexes 1-4 concentrations. Experiments carried out at $298 \mathrm{~K}$, in a Tris- $\mathrm{HCl}$ buffer $/ 30 \%$ DMSO, pH 7.4.

Investigation of the interaction of the complexes 1-4 with DNA through SWV indicates a shift of the redox potential toward negative values with $\Delta 32 \mathrm{mV}$ for $\mathbf{1}$; $\Delta 79 \mathrm{mV}$ for $\mathbf{2} ; \Delta 33$ for $\mathbf{3}$ and $\Delta 41 \mathrm{mV}$ for $\mathbf{4}$ (see Figure 3). It is well known that when a potential shift to higher
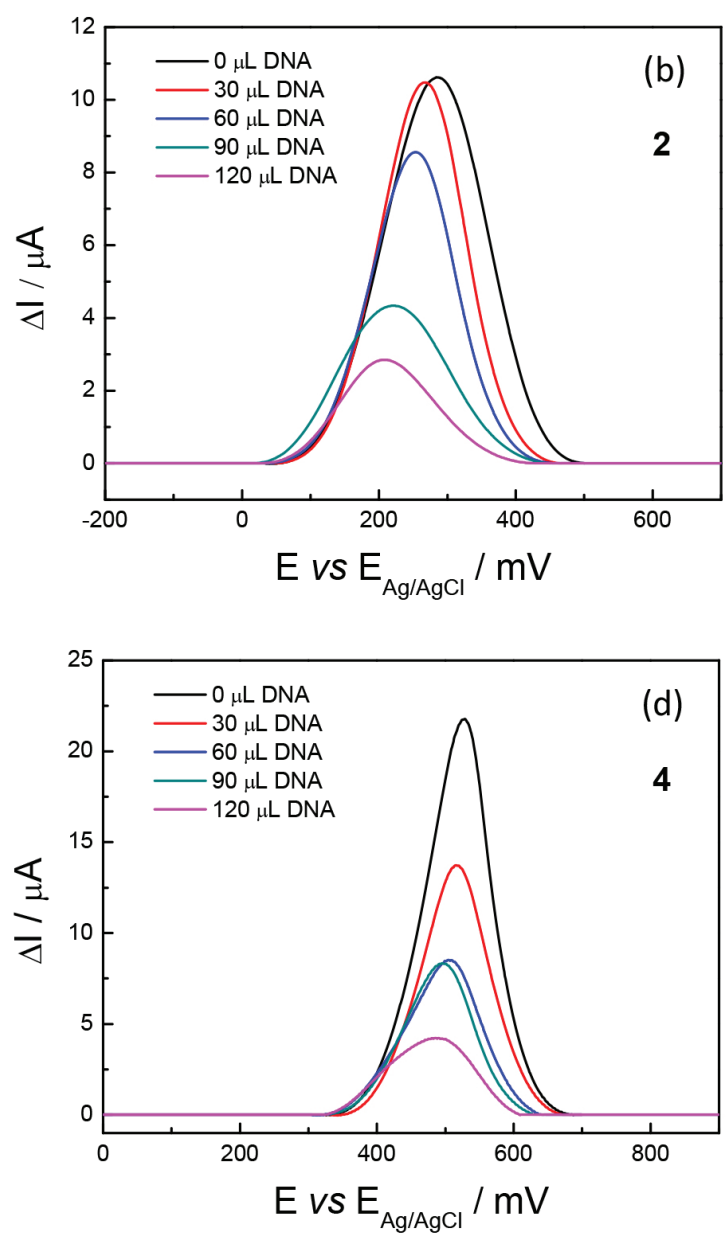

Figure 3. Square-wave voltammogram of $1.0 \mathrm{mM}$ of complexes (a) 1, (b) 2, (c) $\mathbf{3}$ and (d) $\mathbf{4}$ at the GC electrode in Tris- $\mathrm{HCl}$ buffer (pH 7.4), 30\% DMSO was used as a supporting electrolyte, DNA $4.2 \mu \mathrm{M}$. Frequency $50 \mathrm{~Hz}$, pulse height $75 \mathrm{mV}$ and potential increment $2 \mathrm{mV}$. 
power values indicates an interaction by intercalation, and on the other hand, when the displacement of the potential is for lower values, this indicates a weak interaction between the complex and the DNA, such as hydrogen bonding through the major or minor groove of the DNA or by electrostatic interactions between the complexes and the biomolecule. ${ }^{27}$ Thus, although complex $\mathbf{3}$ and complex 4 can be charged in solution at $\mathrm{pH} 7$, positively and negatively, respectively, the shift $(\Delta)$ of their redox potentials, similar to the shift of the neutral complex $\mathbf{1}$, this rules out an electrostatic interaction between the complexes and the DNA molecule.

In Figure 3, the current of the peaks changes differently, which can be a consequence of the different intensity of the interaction complex/DNA. In this case, the diffusion of the solutions of the complexes are different, causing a different intensity of the peaks.

The ability of compounds to modify the tertiary structure of DNA has also been examined by monitoring changes in the electrophoretic mobility of plasmid in gel agarose. ${ }^{37}$ This prompted a study aiming to evaluate the electrophoretic mobility of plasmid pBlue-Script KSII(+) DNA in agarose after incubation of ruthenium complexes for $18 \mathrm{~h}$ at $37^{\circ} \mathrm{C}$ (compound: DNA Ri 0.5, 1.0 and 2.0) compared to free pBlue-Script KSII(+) (Figure 4, lines 1 and 12) and pBlue-Script $\mathrm{KSII}(+)$ treated with DMSO (Figure 4, lines 2 and 13). The results showed that exposure of pBlue-Script KSII(+) to increasing complex concentrations did not induce a noticeable alteration in the structure of the plasmid under these conditions (see Figure 4).

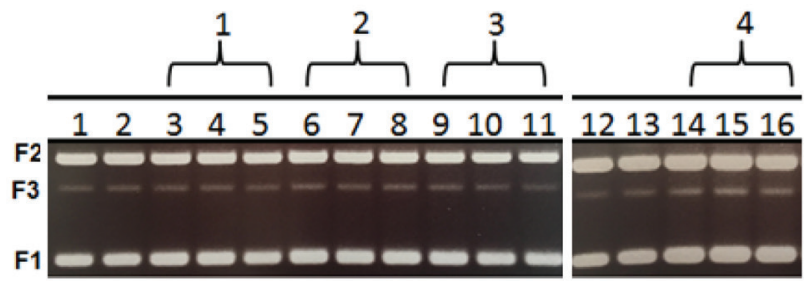

Figure 4. Electrophoresis of plasmid pBlue-Script $\mathrm{KSII}(+)$ incubated in $5 \mathrm{mMTris} / \mathrm{HCl}$ buffer for $18 \mathrm{~h}$ at $37^{\circ} \mathrm{C}$ treated with $0.5,1.0$ and $2.0 \mathrm{eq}$. of complexes 1-4, lanes 1 and 12: pBlue-Script KSII(+); lanes 2 and 13: pBlue-Script KSII(+) treated with DMSO.

In conclusion, the data obtained enable us to suggest that the ruthenium(II) compounds present DNA binding affinity, primarily through weak interactions, such as hydrogen bonding, by major or minor groove. Also, our complexes, which possess methylene groups of the dppb ligand, can bind to DNA by van der Waals interaction between the methylene groups and the thymine methyl group. ${ }^{38}$

\section{Topoisomerase IB activity in vitro}

\section{DNA relaxation assay}

Human topoisomerase IB (TopIB) is a monomeric enzyme that catalyzes the relaxation of supercoiled DNA and controls its topological state. TopIB comprises 765 amino acid residues, divided into four domains: the N-terminal (1-214), the core (215-635), the linker (636-712) and the C-terminal domain (713-765). ${ }^{39,40}$

The inhibition potency of ruthenium complexes 1-4 on the ability of TopIB enzyme to relax the supercoiled plasmid substrate has been assayed incubating a supercoiled plasmid with the enzyme in the absence or presence of different complex concentrations, stopping the reaction with SDS, after $30 \mathrm{~min}$ of incubation and resolving the products by agarose gel electrophoresis (see Figure 5). Only complex $\mathbf{2}$ exhibits full inhibitory activity, which is the most active, since a full TopIB inhibition is achieved at $50 \mu \mathrm{M}$. In the absence of enzyme, the band of the supercoiled plasmid presents an identical height in the absence and presence of a large concentration of complex indicating that none of the four compounds interacts with the DNA substrate. After pre-incubation, all the complexes increase the active inhibition at a lower concentration. Complex 1 does not interfere in the topoisomerase activity. Interestingly, this complex also showed no cytotoxic activity in the cell lines studied. Another fact related to this supposition is that complex $\mathbf{2}$, which was the only one that completely inhibited the activity of topoisomerase is also the complex that has a higher cytotoxic activity, among the four compounds. The other complexes showed an early inhibition of topoisomerase activity, but this inhibition was not complete, however these complexes showed some cytotoxic activity, unlike complex 1 .

When complex 2 was pre-incubated with the enzyme at the concentration of $7.5 \mu \mathrm{mol} \mathrm{L}{ }^{-1}$ (6.6 times lower than the necessary to inhibit the enzyme without previous incubation), this condition was sufficient to cause a complete inhibition of TopIB activity. In detail, this concentration of complex 2 fully inhibits the enzyme when pre-incubated for $5 \mathrm{~min}$ before adding the DNA substrate, suggesting that the compound directly interacts with the enzyme (Figure 5B, lanes 11-13).

Camargo et al., ${ }^{41}$ in a study on the complexes $\left[\mathrm{Ru}(\mathrm{Spy})(\right.$ bipy)(dppb) $] \mathrm{PF}_{6},\left[\mathrm{Ru}(\mathrm{Spym})(\right.$ bipy)(dppb) $] \mathrm{PF}_{6}$ and [Ru ( S p y m M e 2) (b i p y ) ( d p p b ) ] P F 6 $\left(\mathrm{Spy}^{-}=2\right.$-mercaptopyridine anion; $\mathrm{Spym}^{-}=2$-mercaptopyrimidine anion and $\mathrm{SpymMe}_{2}^{-}=4,6$-dimethyl2-mercaptopyrimidine anion), showed that compound $\left[\mathrm{Ru}\left(\mathrm{SpymMe}_{2}\right)\right.$ (bipy)(dppb)]PF $\mathrm{PF}_{6}$ was the most efficient as topoisomerase IB inhibitor, and that the inhibitory 
(a)

(A)

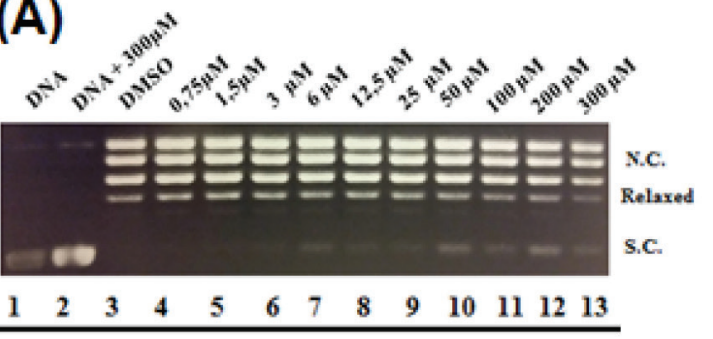

(b)

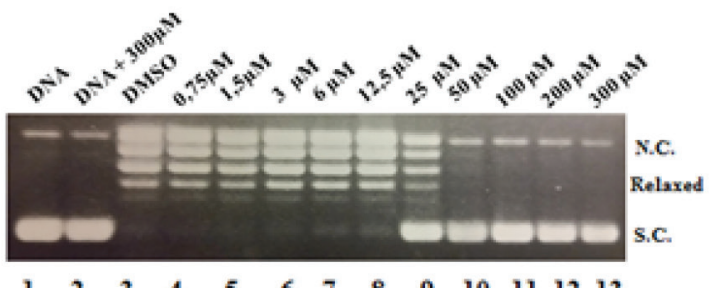

$\begin{array}{lllllllllllll}1 & 2 & 3 & 4 & 5 & 6 & 7 & 8 & 9 & 10 & 11 & 12 & 13\end{array}$
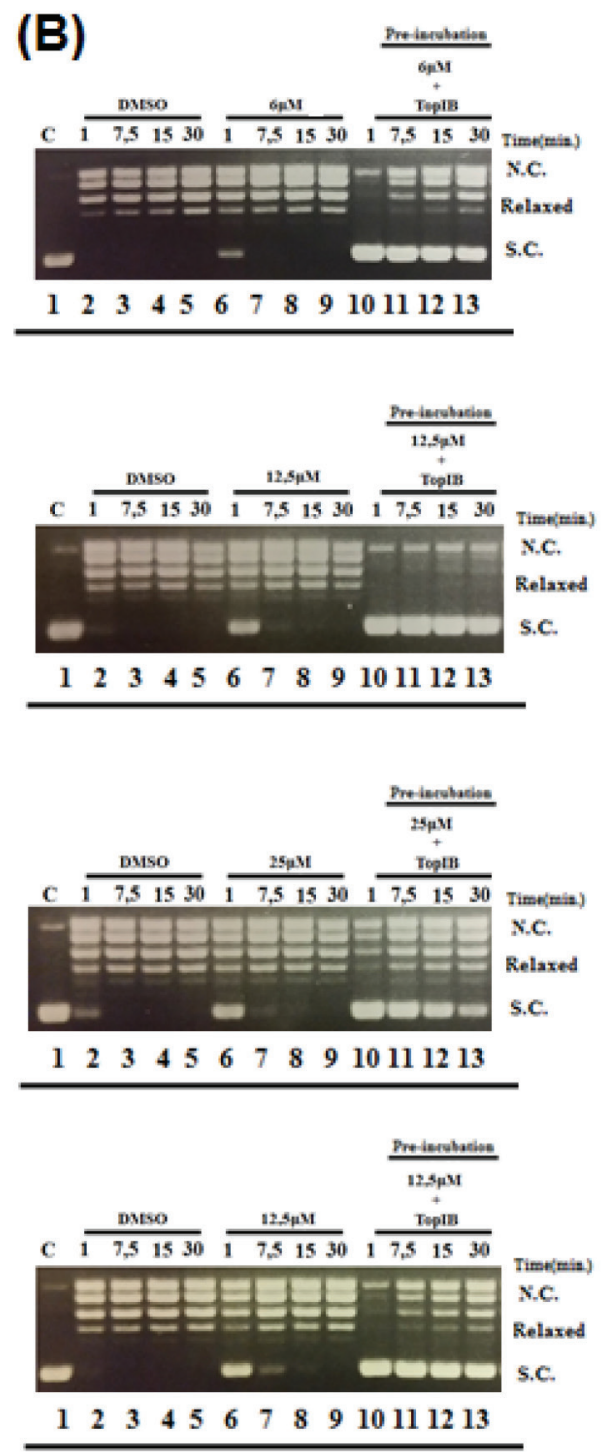

Figure 5. (A) Relaxation of negative supercoiled plasmid DNA by topoisomerase IB in the presence of increasing concentrations of complexes (a) 1 , (b) 2 , (c) 3 and (d) 4 . The reaction products were resolved in an agarose gel and visualized with ethidium bromide. Lane 1, DNA substrate. Lane 2, DNA plus $300 \mu \mathrm{M}$ complex. Lane 3, DNA, DMSO plus enzyme. NC: nicked circular plasmid DNA.SC: supercoiled plasmid DNA. (B) Relaxation of negative supercoiled plasmid DNA in a time course experiment with DMSO (lanes 2-5), in the presence of complex (lanes 6-9), after pre-incubation enzyme and complex for $5 \mathrm{~min}$ at $37^{\circ} \mathrm{C}$ (lanes 10-13). Lane 1 , no protein added.

capacity of the complexes was also enhanced upon their pre-incubation. Molecular docking confirmed the direct interaction between complex $\mathbf{3}$ and enzyme, showing that the complex $\left[\mathrm{Ru}\left(\mathrm{SpymMe}_{2}\right)(\mathrm{bipy})(\mathrm{dppb})\right] \mathrm{PF}_{6}$ preferentially binds closer to residues of active site when TopIB is free.

\section{Analysis of cleavage and reconnection kinetics}

The cleavage and reconnection reactions were performed in separate experiments, only with complex $\mathbf{2}$, the most potent TopIB inhibitor. These experiments were carried out to identify if complex 2 affects one or both steps of the catalytic cycle. The cleavage kinetics was assayed in a time-course reaction with the asymmetric
CL14/CP25 substrate, radiolabelled at the 5' end of the short strand, containing the preferred cleavage site for the TopIB, indicated by an arrow in Figure 6a. The kinetics of cleavage was assayed by reacting TopIB with the suicide substrate, in the absence and presence of compounds. Analysis of the reaction products are shown in Figure 6b. The cleavage kinetics is fast in the absence of the complex, where the TopIB is inhibited slower in the presence of $50 \mu \mathrm{M}$ complex 2 , cleaves $60 \%$ of the enzyme, inhibiting approximately $40 \%$ of cleavage. This step characterizes the catalytic cycle of the TopIB enzyme (see Figure 6c).

The reconnection kinetics was carried out incubating the suicide cleavage substrate with TopIB for 30 min to produce 
(a)

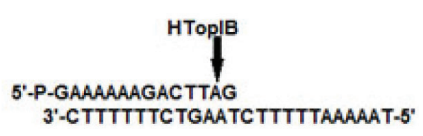

3'-CTTTTTTCTGAATCTTTTTAAAAAT-5'
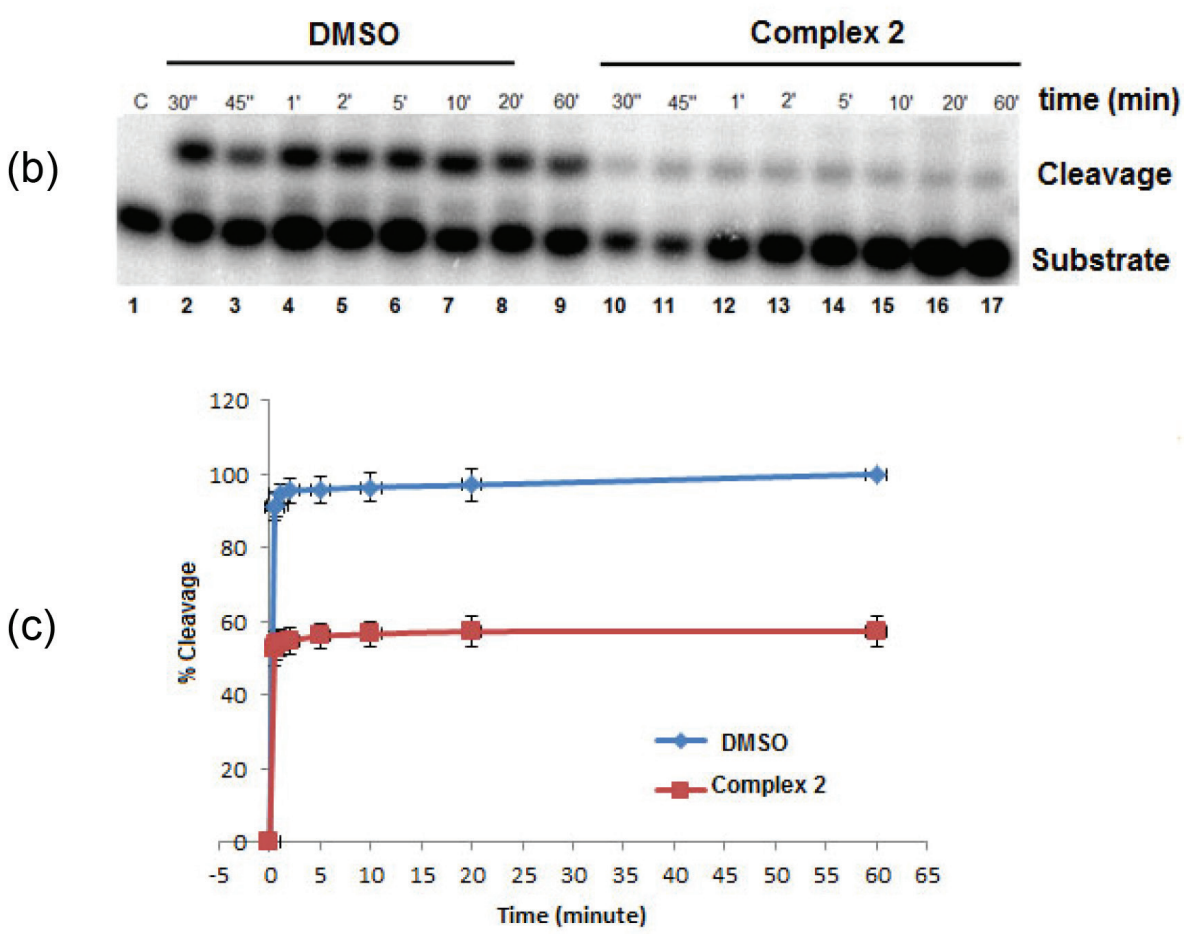

Figure 6. (a) The CL14/CP25 suicide substrate used to measure the cleavage kinetics of the enzyme. The preferred TopIB binding site is indicated by an arrow. (b) Cleavage kinetics of Top1 in the presence of DMSO (lanes 2-9) and in the presence of $50 \mu \mathrm{M}$ complex 2 (lanes 10-17). (c) Percentage of the cleaved product plotted at different times for TopIB in the absence and presence of complex 2.

the cleaved complex, followed by a subsequent addition of 200-fold molar excess of the R11 complementary oligonucleotide in the presence of DMSO or complex 2. The data show that the reconnection kinetics of TopIB (Figure 7b, lanes 2-10) is different in the presence of $50 \mu \mathrm{M}$ of complex 2 (Figure 6b, lanes 11-19). It showed a significant effect in the quantification of approximately $60 \%$ (Figure 7c). In other words, complex 2 also inhibits the reconnection step. That is, complex $\mathbf{2}$ can be considered a mixed inhibitor, inhibiting the activity of the TopIB, cleavage step and the reconnection step.

Inhibitors considered TopIB poisons stabilize an intermediary covalent complex, named cleavable complex, maintaining the breaks of DNA strands, promoting stagnation in cell cycle and, finally, triggering the apoptosis. ${ }^{42}$ Other compounds do not enhance DNA breakage but inhibit the enzyme catalytic activity, and we here reserve the term 'inhibitor' for these agents only. In particular, some inhibitors bind to the DNA and in doing so impede the access of topoisomerases to DNA sequences. ${ }^{43}$

It is important to point out that while there are numerous reports in the literature demonstrating the potential of ruthenium(II) complexes focusing on DNA interaction, very little attention has been paid to the interaction of these complexes with the topoisomerase enzyme. Thus, our findings indicate that the anticancer activity of complexes 2-4 might be related to the inhibition of the enzyme DNAtopoisomeraseIB, similar to that one found for ruthenium(II)/ phosphine/diimine/picolinate complexes. ${ }^{44}$

Alpan et $a l .{ }^{45}$ reported several benzimidazole derivatives as inhibitors of type I DNA topoisomerases: 5-chloro-4-( $1 H$-benzimidazole-2-yl)phenol, 5-methyl-4-(1H-benzimida-zole-2-yl)phenol and 4-(1H-benzimidazole-2-yl)phenol. The compound 5-methyl-4-(1H-benzimidazole-2-yl)phenol manifested potent topoisomerase I inhibition, which could be explained by the presence of the methyl group in the molecule. Also, in our study, the complex $\mathbf{2}$, containing the methyl group in the ligand, was the compound with the best activity on Top IB inhibition, suggesting that the presence of this group can make difference in the activity of the complex.

\section{Conclusions}

The synthesis of four new ruthenium compounds was presented: $\left[\mathrm{Ru}(\mathrm{mtz})_{2}(\mathrm{dppb})\right](\mathbf{1}),\left[\mathrm{Ru}(\mathrm{mmi})_{2}(\mathrm{dppb})\right](\mathbf{2})$, 
(a)

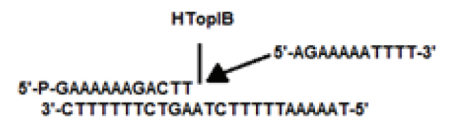

3.-CTTTTTTCTGAATCTTTTTAAAAAT-5:

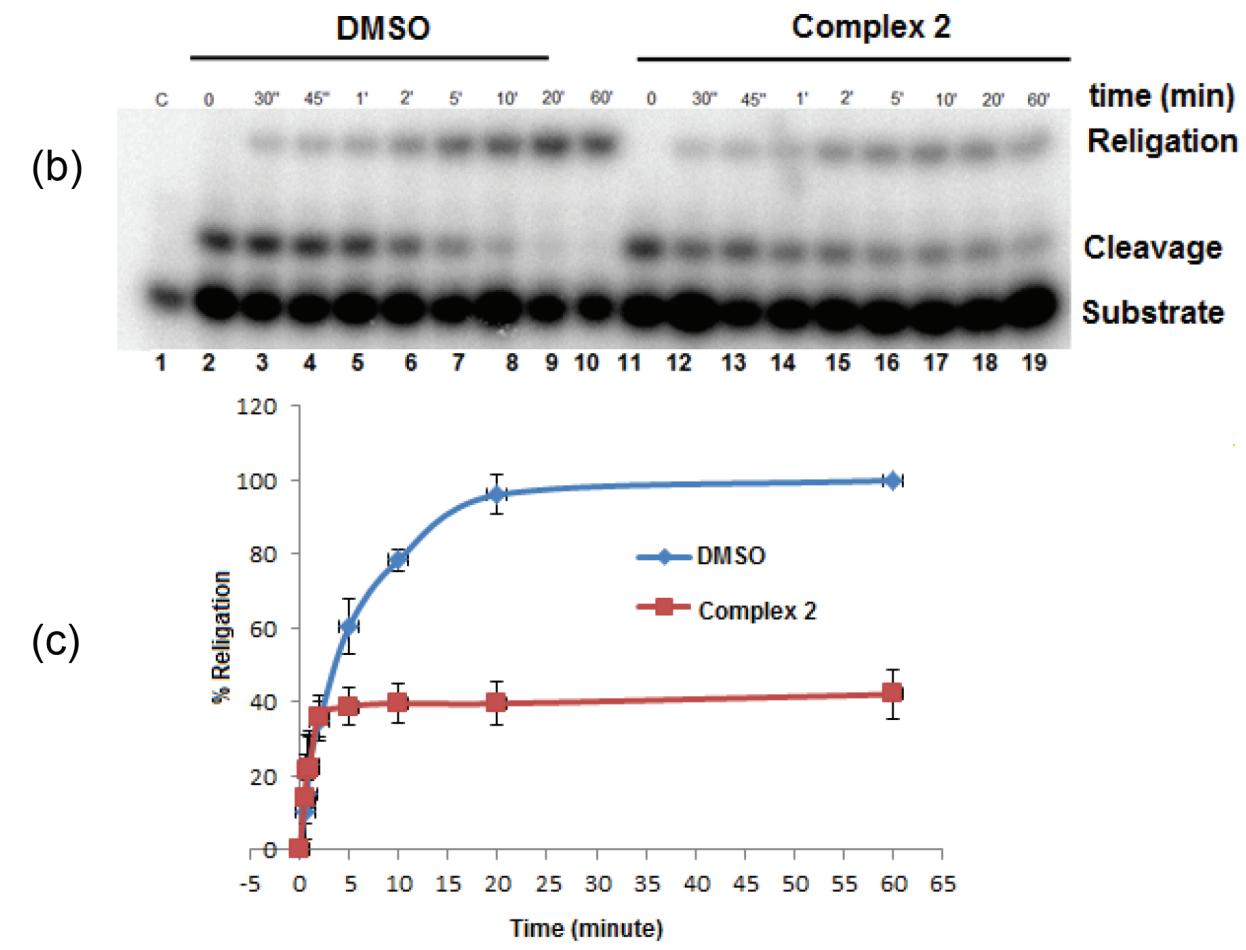

Figure 7. (a) The suicide substrate CL14/CP25 and the R11 complementary oligonucleotide used to measure the reconnection kinetics of the enzyme. (b) Urea polyacrylamide gel electrophoretic analysis of the religation kinetics of TopIB in the absence (lanes 2-10) or presence of $50 \mu \mathrm{M}$ complex 2 (lanes 11-19). Lane 1 represents the substrate alone. (c) The percentage of the reconnection product plotted at different times for TopIB in the absence and presence of complex 2.

$\left[\operatorname{Ru}(\mathrm{dmp})_{2}(\mathrm{dppb})\right](\mathbf{3})$, and $\left[\mathrm{Ru}(\mathrm{mpca})_{2}(\mathrm{dppb})\right](\mathbf{4})$, which were characterized by spectroscopy, cyclic voltammetry and X-ray crystallography. Complexes 1-4 present DNA binding affinity, primarily through weak interactions, such as hydrogen bonding or by major or minor groove interaction, which is plausible considering the neutral charge of the complexes. Our findings show that cytotoxic activity of the complexes may be related to their activity of inhibition of the enzyme topoisomerase IB. Complex 1 showed no cytotoxic activity in any of the studied strains and showed no inhibitory activity of the enzyme. Complex 2 showed the best cytotoxic activity among all the four complexes presented here and is the only one that fully inhibits the topoisomerase IB enzyme activity. Complex $\mathbf{2}$ can be considered a mixed inhibitor, inhibiting both the cleavage and the reconnection steps, and it can be taken into consideration as a promising anticancer metallodrug.

\section{Supplementary Information}

Crystallographic data (excluding structure factors) for the structures in this work were deposited in the Cambridge
Crystallographic Data Centre as supplementary publication number CCDC 1813575 (1), CCDC 1813574 (2), CCDC 1811880 (3) and CCDC 1811881 (4). Copies of the data can be obtained, free of charge, via www.ccdc. cam.ac.uk/conts/retrieving.html or from the Cambridge Crystallographic Data Centre, CCDC, 12 Union Road, Cambridge CB2 1EZ, UK; fax: +44 1223 336033. E-mail: deposit@ccdc.cam.ac.uk.

Supplementary information is available free of charge at http://jbcs.sbq.org.br as PDF file.

\section{Acknowledgments}

The authors are grateful for the support provided by CAPES - Coordination for the Improvement of Higher Education Personnel, FAPESP - São Paulo Research Foundation and CNPq - National Council for Scientific and Technological Development.

\section{References}

1. Corbi, P. P.; Andrade, F. C.; Massabni, A. C.; Heinrich, T. A.; 
Souza, P. P. C.; Costa-Neto, C. M.; Spectrochim. Acta, Part A 2008, 7, 929.

2. Rabie, U. M.; About-El-Wafa, M. H. M.; Nassar, H.; Spectrochim. Acta, Part A 2011, 78, 512.

3. El-Khateeb, M.; Damer, K.; Gorls, H.; Weigan, W.; J. Organomet. Chem. 2007, 692, 2227.

4. Cini, R.; Tamasi, G.; Defazio, S.; Corsini, M.; Berrettini, F.; Cavaglioni, A.; Polyhedron 2006, 25, 834.

5. Alagesan, M.; Bhuvanesh, N. S.; Dharmaraj, N.; Dalton Trans. 2013, 42, 7210 .

6. Liu, Y.; Kumar, A.; Depauw, S.; Nhili, R.; Cordonnier, M.-H. D.; Lee, M. P.; Ismail, M. A.; Farahat, A. A.; Say, M.; Catoen, S. C.; Parra, A. B.; Neidle, S.; Boykin, D. W.; Wilson, W. D.; J. Am. Chem. Soc. 2011, 133, 10171.

7. Pommier, Y.; Pourquier, P.; Fan, Y.; Strumberg, D.; Biochim. Biophys. Acta, Gene Struct. Expression 1998, 1400, 83.

8. Bruning, A.; Mylonas, I.; Arch. Gynecol. Obstet. 2011, 283, 1087.

9. Zhang, C. X.; Lippard, S. J.; Curr. Opin. Chem. Biol. 2003, 7, 481.

10. Webb, M. I.; Walsby, C. J.; Dalton Trans. 2011, 40, 1322.

11. Hartinger, C. G.; Jakupeca, M. A.; Zorbas-Seifrieda, S.; Groessla, M.; Eggera, A.; Bergerd, W.; Zorbasc, H.; Dysonb, P. J.; Keppler, B. K.; Chem. Biodiversity 2008, 5, 2140.

12. Trondl, R.; Heffeter, P.; Kowol, C. R.; Jakupec, M. A.; Berger, W.; Keppler, B. K.; Chem. Sci. 2014, 5, 2925.

13. Kuhn, P. S.; Pichler, V.; Roller, A.; Hejl, M.; Jakupec, M. A.; Kandioller, W.; Keppler, B. K.; Dalton Trans. 2015, 44, 659.

14. Alessio, E.; Eur. J. Inorg. Chem. 2017, 12, 1549.

15. Via, L. D.; Marzaro, G.; Ferrarese, A.; Gia, O.; Chilin, A.; Eur. J. Med. Chem. 2014, 77, 103.

16. Branco, A.; Pinto, A. C.; Braz-Filho, R.; Silva, E. F.; Grynberg, N. F.; Echevarria, A.; Rev. Bras. Farmacogn. 2008, 18, 703.

17. Parchment, R. E.; Pessin, A.; Cytotechnology 1998, 27, 149.

18. Katkar, P.; Coletta, A.; Castelli, S.; Sabino, G. L.; Couto, R. A.; Ferreira, A. M.; Desideri, A.; Metallomics 2014, 6, 117.

19. Pommier, Y.; Chem. Rev. 2009, 109, 2894.

20. Arno, B.; Coletta, A.; Tesauro, C.; Zuccaro, L.; Fiorani, P.; Lentini, S.; Galloni, P.; Conte, V.; Floris, B.; Desideri, A.; Biosci. Rep. 2013, 33, 269.

21. Bressan, M.; Rigo, P.; Inorg. Chem. 1975, 14, 2286.

22. Queiroz, S. L.; Batista, A. A.; Oliva, G.; Gambardella, M. T. P.; Santos, R. H.; MacFarlane, K. S.; James, B. R.; Inorg. Chim. Acta 1998, 276, 209.

23. Sheldrick, M.; Acta Cryst. A 2008, 64, 112.

24. Spek, A. L.; J. Appl. Crystallogr. 2003, 36, 7.

25. Baka, E.; Comer, J. E. A.; Takács-Novák, K.; J. Pharm. Biomed. Anal. 2008, 46, 335.

26. Macquet, J. P.; Butour, J. L.; Eur. J. Biochem. 1978, 83, 375.

27. Sirajuddin, M.; Ali, S.; Badshah, A.; J. Photochem. Photobiol., B 2013, 124, 1.
28. Carter, M. T.; Bard, A.; J. Am. Chem. Soc. 1987, 24, 7528.

29. Chillemi, G.; Fiorano, P.; Castelli, S.; Bruselles, A.; Benedetti, P.; Desideri, A.; Acids Res. 2005, 33, 3339.

30. Geary, W. J.; Coord. Chem. Rev. 1971, 7, 81.

31. Mondelli, M. A.; Graminha, A. E.; Corrêa, R. S.; da Silva, M. M.; Carnizello, A. P.; Poelhsitz, G. V.; Ellena, J.; Deflon, V. M.; Caramori, G. F.; Torre, M. H.; Tavares, D. C.; Batista, A. A.; Polyhedron 2014, 68, 312.

32. Velozo-Sá, V. S.; Pereira, L. R.; Lima, A. P.; Mello-Andrade, F.; Rezende, M. M.; Goveia, R. M.; Pires, W. C.; Silva, M. M.; Oliveira, K. M.; Ferreira, A. G.; Ellena, J.; Deflon, V. M.; Grisolia, C. K.; Batista, A. A.; Silveira-Lacerda, E. P.; Dalton Trans. 2019, 48, 6026.

33. Corrêa, R. S.; da Silva, M. M.; Graminha, A. E.; Meira, C. S.; Santos, J. A.; Moreira, D. R.; Soares, M. B.; Poelhsitz, G. V.; Castellano, E. E.; Bloch Jr., C.; Cominetti, M. R.; Batista, A. A.; J. Inorg. Biochem. 2016, 156, 153.

34. Wilson, J. J.; Lippard, S.; J. Med. Chem. 2012, 55, 5326.

35. Pliska, V.; Testa, B.; Waterbeemd, H. V.; In Lipophilicity in Drug Action and Toxicology, $1^{\text {st }}$ ed.; Pliska, V.; Testa, B.; Waterbeemd, H., eds.; VHC: Weinheim, Germany, 1996.

36. Villareal, W.; Colina-Vegas, L.; de Oliveira, C. R.; Tenorio, J. C.; Ellena, J.; Gozzo, F.; Cominetti, M. R.; Ferreira, A. G.; Ferreira, M. A. B.; Navarro, M.; Batista, A. A.; Inorg. Chem. 2015, 54, 11709.

37. Gallori, E.; Vettori, C.; Alessio, E.; Gonzalez-Vilchez, F.; Vilapana, R. A.; Orioli, P.; Casini, A.; Messori, L.; Arch. Biochem. Biophys. 2000, 376, 156.

38. Liu, C. L.; Zhou, J. Y.; Li, Q. X.; Wang, L. J.; Liao, Z. R.; Xu, H. B.; J. Inorg. Biochem. 1999, 75, 233.

39. Redinbo, M. R.; Champoux, J. J.; Hol, W. G.; Biochemistry 2000, 39, 6832.

40. Redinbo, M. R.; Stewart, L.; Champoux, J. J.; Hol, W. G.; J. Mol. Biol. 1999, 292, 685.

41. Camargo, M. S.; Silva, M. M.; Correa, R. S.; Vieira, S. D.; Castelli, S.; D’Anessa, I.; de Grandis, R.; Varanda, E.; Deflon, V. M.; Desideri, A.; Batista, A. A.; Metallomics 2016, 8, 179.

42. Capranico, G.; Binaschi, M.; Borgnetto, M. E.; Zunino, F.; Palumbo, M.; Trends Pharmacol. Sci. 1997, 18, 323.

43. Almeida, S. M. V.; Ribeiro, A. G.; Silva, G. C. L.; Alves, J. E. F.; Beltrão, E. I. C.; Oliveira Jr., J. F.; de Lima, M. D. C. A.; Biomed. Pharmacother. 2017, 96, 1538.

44. de Grandis, R. A.; Camargo, M. S.; da Silva, M. M.; Lopes, E. O.; Padilha, E. C.; Resende, F. A.; Peccinini, R. G.; Pavan, F. R.; Desideri, A.; Batista, A. A.; Varanda, E. A.; BioMetals 2017, 30, 321.

45. Alpan, A. S.; Gunes, H. S.; Topcu, Z.; Acta Biochim. Pol. 2007, 54,561 .

Submitted: December 31, 2018 Published online: September 3, 2019 